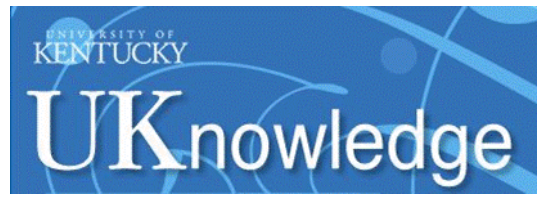

University of Kentucky UKnowledge

2006

\title{
The Speciation of Metals in Mammals Influences Their Toxicokinetics and Toxicodynamics and Therefore Human Health Risk Assessment
}

Robert A. Yokel

University of Kentucky, ryokel@email.uky.edu

Stephen M. Lasley

University of Illinois

David C. Dorman

CIIT Centers for Health Research

Right click to open a feedback form in a new tab to let us know how this document benefits you. Follow this and additional works at: https://uknowledge.uky.edu/ps_facpub

Part of the Pharmacy and Pharmaceutical Sciences Commons, and the Toxicology Commons 


\title{
The Speciation of Metals in Mammals Influences Their Toxicokinetics and Toxicodynamics and Therefore Human Health Risk Assessment
}

\author{
Digital Object Identifier (DOI) \\ https://doi.org/10.1080/15287390500196230 \\ Notes/Citation Information \\ Published in the Journal of Toxicology and Environmental Health, Part B, v. 9, issue 1.
}

This is an Accepted Manuscript version of the following article, accepted for publication in Journal of Toxicology and Environmental Health, Part $B$.

Yokel, R. A., Lasley, S. M., \& Dorman, D. C. (2006). The speciation of metals in mammals influences their toxicokinetics and toxicodynamics and therefore human health risk assessment. Journal of Toxicology and Environmental Health, Part B, 9(1), 63-85. https://doi.org/10.1080/15287390500196230

It is deposited under the terms of the Creative Commons Attribution-NonCommercial-NoDerivatives License (https://creativecommons.org/licenses/by-nc-nd/4.0/), which permits non-commercial re-use, distribution, and reproduction in any medium, provided the original work is properly cited, and is not altered, transformed, or built upon in any way. 


\section{THE SPECIATION OF METALS IN MAMMALS INFLUENCES THEIR \\ TOXICOKINETICS AND TOXICODYNAMICS AND THEREFORE HUMAN HEALTH \\ RISK ASSESSMENT ${ }^{1}$}

Robert A. Yokel

Pharmaceutical Sciences, College of Pharmacy, and Graduate Center for Toxicology, University of Kentucky Medical Center, Lexington, KY, 40536-0082

Stephen M. Lasley

Department of Biomedical \& Therapeutic Sciences, University of Illinois College of Medicine, Peoria, IL, 61656

David C. Dorman

CIIT Centers for Health Research, Research Triangle Park, NC, 27709.

${ }^{1}$ This article is based on a workshop entitled "Metal Speciation in Toxicology:

Determination and Importance for Risk Assessment" presented at the $42^{\text {nd }}$ Annual Meeting of the Society of Toxicology, March, 2003, Salt Lake City, UT.

Address correspondence to Robert A. Yokel, Pharmaceutical Sciences, College of Pharmacy, 511C Pharmacy Building, 725 Rose Street, University of Kentucky Medical Center, Lexington, KY 40536-0082, USA. Email: ryokel@email.uky.edu

Running title: Metal speciation matters 


\section{ABSTRACT:}

Chemical form (i.e., species) can influence metal toxicokinetics and toxicodynamics and should be considered to improve human health risk assessment. Factors that influence metal speciation (and examples) include: (1) carrier-mediated processes for specific metal species (arsenic, chromium, lead, and manganese), (2) valence state (arsenic, chromium, manganese, and mercury), (3) particle size (lead and manganese), (4) the nature of metal binding ligands (aluminum, arsenic, chromium, lead and manganese), (5) whether the metal is an organic versus inorganic species (arsenic, lead and mercury), and (6) biotransformation of metal species (aluminum, arsenic, chromium, lead, manganese, and mercury). The influence of speciation on metal toxicokinetics and toxicodynamics in mammals, and therefore the adverse effects of metals, is reviewed to illustrate how the physicochemical characteristics of metals and their handling in the body (toxicokinetics) can influence toxicity (toxicodynamics). Generalizing from mercury, arsenic, lead, aluminum, chromium, and manganese, it is clear that metal speciation influences mammalian toxicity. Methods used in aquatic toxicology to predict the interaction among metal speciation, uptake and toxicity are evaluated. A classification system is presented to show that the chemical nature of the metal can predict metal ion toxicokinetics and toxicodynamics. Essential metals, such as iron, are considered. These metals produce low oral toxicity under most exposure conditions but become toxic when biological processes that utilize or transport them are overwhelmed, or bypassed. Risk assessments for essential and nonessential metals should consider toxicokinetic and toxicodynamic factors in setting exposure standards. Because 
speciation can influence a metal's fate and toxicity, different exposure standards should be established for different metal species. Many examples are provided which consider metal essentiality and toxicity and that illustrate how consideration of metal speciation can improve the risk assessment process. More examples are available at a website established as a repository for summaries of the literature on how the speciation of metals affects their toxicokinetics.

Key words: Metal speciation, risk assessment, toxicodynamics, toxicokinetics

\section{Abbreviations:}

Ag silver

Al aluminum

Am americium

As arsenic

At astatine

Au gold

$\mathrm{Ba}$ barium

Be beryllium

$\mathrm{Bi}$ bismuth

B boron

Ca calcium

Cd cadmium

Co cobalt

$\mathrm{Cr} \quad$ chromium 


\begin{tabular}{|c|c|}
\hline $\mathrm{Cu}$ & copper \\
\hline $\mathrm{Fe}$ & iron \\
\hline $\mathrm{Ga}$ & gallium \\
\hline $\mathrm{Ge}$ & germanium \\
\hline Gd & gadolinium \\
\hline $\mathrm{Hg}$ & mercury \\
\hline I & iodine \\
\hline $\ln$ & indium \\
\hline $\mathrm{K}$ & potassium \\
\hline $\mathrm{Li}$ & lithium \\
\hline $\mathrm{Mg}$ & magnesium \\
\hline $\mathrm{Mn}$ & manganese \\
\hline Mo & molybdenum \\
\hline $\mathrm{Na}$ & sodium \\
\hline $\mathrm{Ni}$ & nickel \\
\hline $\mathrm{Pb}$ & lead \\
\hline Po & polonium \\
\hline $\mathrm{Pt}$ & platinum \\
\hline $\mathrm{Pu}$ & plutonium \\
\hline $\mathrm{Ra}$ & radium \\
\hline $\mathrm{Rb}$ & rubidium \\
\hline $\mathrm{Sb}$ & antimony \\
\hline Se & seleniun \\
\hline
\end{tabular}




$\begin{array}{ll}\mathrm{Si} & \text { silicon } \\ \mathrm{Sn} & \text { tin } \\ \mathrm{Sr} & \text { strontium } \\ \mathrm{Te} & \text { tellerium } \\ \mathrm{Th} & \text { thorium } \\ \mathrm{Ti} & \text { titanium } \\ \mathrm{TI} & \text { thallium } \\ \mathrm{U} & \text { uranium } \\ \mathrm{V} & \text { vanadium } \\ \mathrm{Zn} & \text { zinc } \\ \mathrm{Zr} & \text { zirconium }\end{array}$




\section{INTRODUCTION:}

There are important relationships between chemical speciation and toxicity for many toxic metals. Defining these relationships advances the understanding of mechanisms and treatments of toxicity and can improve risk assessment. This paper reviews the impact of speciation on the fate of metals; the interaction of biotransformation with absorption, distribution and elimination; the impact of speciation on metal toxicity; and how metal speciation might be incorporated into risk assessment. The impacts of valence state, isotope, associated ligands and inorganic and organic species on the fate of metals and their adverse effects are illustrated with many examples. Metal speciation and associated mechanisms of toxicity in mammals are reviewed with the objective of determining whether the relationships between speciation and metal fate and toxicity are empirical, or if models or systems can predict mammalian toxicity on the basis of chemical properties with the goal of their application in risk assessment. The companion paper presents the chemical separation and analytical detection methods most commonly used to speciate metals (Caruso et al., 2005). It also presents a computational approach to metal speciation based on stability constants and concentrations of the metal and interacting ligands that can be used with some metals when physical separation and detection methods are not applicable or have not been developed.

It is well recognized that a metal's species can influence its fate in the environment and in organisms, and therefore its toxicity. However, most regulations in international legislation concerning trace elements in food, the environment and occupational settings are based on the total amount of the element rather than 
individual chemical forms (Larsen and Berg, 2001). Chemical speciation is a problem for the risk assessor because regulations concerning trace element exposure levels usually ignore the impact of chemical species on bioavailability and toxicity. Elements other than carbon are typically regulated as classes of compounds containing a named element rather than specific chemical forms (Duffus, 2001). This review illustrates why metal speciation matters.

\section{What is Metal Speciation?}

There is not a uniformly accepted definition of metal speciation. It has been suggested that such a definition would reduce confusion (Bernhard et al., 1986; Swietlik, 1998). A definition developed by the First, Second and Third International Symposia on Speciation of Elements in Toxicology and Environmental and Biological Sciences in 1991, 1994 and 1997 states: "Speciation is the occurrence of an element in separate, identifiable forms (i.e., chemical, physical or morphological state)" (Nieboer et al., 1999). This definition is not limited to a strict chemical perspective as it recognizes that compounds of elements can occur in different physical states and that the state can affect the route and extent of exposure, uptake/absorption and the toxicodynamic results. The International Union for Pure and Appled Chemistry (IUPAC) developed a definition in 1997 recommending that speciation "Refers to the chemical form or compound in which an element occurs in both non-living and living systems. It may also refer to the quantitative distribution of an element". In 2000 the IUPAC recommended definitions that distinguish among the following (Templeton et al., 2000): 
i. Chemical species (of an element): "Specific form of an element defined as to isotopic composition, electronic or oxidation state, and/or complex or molecular structure",

ii. Speciation analysis (in chemistry): "Analytical activities of identifying and/or measuring the quantities of one or more individual chemical species in a sample", and

iii. Speciation (in chemistry). "Distribution of an element amongst defined chemical species in a system."

Developers of the IUPAC definition suggested that speciation analysis be used when referring to the analytical activity of identifying and measuring species; that species transformation ${ }^{1}$ be used to describe the transformations that take place during cycling of the elements in geochemical and environmental contexts; and the term speciation be exclusively reserved to refer to the distribution of species in a particular sample or matrix (Templeton et al, 2000). These terms have been adopted by IUPAC (Nordberg et al., 2004) for inclusion in the next edition of the Compendium of Chemical Terminology, "The Gold book". A recent review suggests that the IUPAC effort to define speciation, although admirable, has components that are difficult to understand; raises questions why the isotopic composition, a nuclear property, is considered a chemical property; and is narrowly defined, in that distribution is only one of several aspects of speciation, which should also include the processes of transformation, alteration and interaction

Footnote $^{1:}$ Because this review focuses on metal speciation in mammals, we discuss transformation in biological organisms, e.g., biotransformation. 
among the chemical species. These authors conclude "... speciation study is now just at the preliminary stage of its developmental process." (Chai et al., 2004). Although there has been discussion between those involved in development of the definition that came out of the International Symposia and by the IUPAC, there are differences among these definitions. There does not appear to be any planned effort to harmonize these definitions. The focus of this review is that differences in metals can impact on the adverse response, and that risk assessment that does not recognize these variables is an oversimplification and does not take full advantage of current knowledge. As it is well known that chemical as well as physical properties can impact on the adverse response, we have considered both in this review.

A variable that contributes to speciation is valence (the combining power of an atom, determined by the number of electrons in the outer shell of the atom that it will lose, add or share when reacting with another atom). Many metals have more than one biologically relevant valence state, discussed below. Another variable contributing to speciation is the isotope (one of two or more nuclides with the usual number of protons but differing in mass number due to a different number of neutrons). A third variable is the associated ligand. A fourth variable is particle size, a form of morphological state. As it has been repeatedly shown that particle size can influence distribution, especially in the lung, and the rate of solubility, we have considered particle size as a variable contributing to metal speciation. Speciation is expected to describe the chemical, physical and temporal behavior of chemical species in biogeochemical systems (Evans, 2003). In this review we consider how physicochemical variables affect metal toxicokinetics and the resulting toxicodynamics in mammals. 


\section{The Metals and a New Database on the Impact of Metal Speciation on}

\section{Toxicokinetics}

Approximately $85 \%$ of the elements are metals and/or metalloids (elements that share properties of both metals and non-metals; $\mathrm{B}, \mathrm{Si}, \mathrm{Ge}, \mathrm{As}, \mathrm{Sb}, \mathrm{Te}, \mathrm{Po}$ and At). Many are essential and/or have considerable toxicity. Although the importance of metal speciation in toxicokinetics and toxicodynamics is appreciated, metal speciation has not been determined in most studies (Boisset, 2000). The impact of metal speciation on metal toxicokinetics and toxicodynamics in aquatic environments has been summarized and integrated to some extent (Ebdon et al., 2001; Paquin et al., 2002) but a focused summary of the effects of speciation in mammalian organisms is lacking. A database has been established to summarize and provide references for the published reports scattered throughout the periodical literature and in books that describe the impact of metal speciation on toxicokinetics in mammals http://www.mc.uky.edu/pharmacy/faculty/yokel/metal-toxicokinetics/. The objectives of this database are to begin to integrate this literature, illustrate the importance of speciation on metal toxicokinetics, and advance the refinement of risk assessment of metals beyond simply consideration of the metal independently of its chemical and physical form. A sample page from the database is shown in Figure 1.This database includes metals that are macronutrients $(\mathrm{Na}, \mathrm{K}, \mathrm{Mg}$ and $\mathrm{Ca}$ ) as well as metals generally considered to be essential for human health in trace amounts $(\mathrm{Cr}, \mathrm{Co}, \mathrm{Cu}, \mathrm{Fe}, \mathrm{Mn}, \mathrm{Mo}$, Se and $\mathrm{Zn}$ ), metals for which there is circumstantial evidence for essentiality ( $\mathrm{As}, \mathrm{Ni}, \mathrm{Si}$ and $\mathrm{V})$ and metals for which the circumstantial evidence is not as convincing $(\mathrm{B}, \mathrm{Cd}$, 
$\mathrm{Ge}, \mathrm{Pb}, \mathrm{Li}, \mathrm{Rb}$, and $\mathrm{Sn}$ ) (Uthus and Seaborn, 1996; Goyer and Clarkson, 2001). It also includes metals for which there is considerable toxicity (As, Be, Cd, Cr, Hg, Ni, Po, Ra, and $\mathrm{Pb}$ ), intermediate toxicity (Co, $\mathrm{Cu}, \mathrm{Fe}, \mathrm{Mg}, \mathrm{Mn}, \mathrm{Mo}$, Se and $\mathrm{Zn}$ ) and those of lesser concern (Al, Ag, Am, Au, B, Ba, Bi, Ca, Ga, Ge, In, Li, Po, Pt, Sb, Sn, Sr, Te, Th, Ti, Tl, $\mathrm{U}$ and $\mathrm{V}$ ) as indicated by the Toxicological Profiles (ATSDR), entries in POISINDEX, the Handbook on the Toxicology of Metals series (Friberg et al., 1979; Friberg et al., 1986), Patty's Toxicology (Bingham et al., 2001) and (Goyer and Clarkson, 2001). It is apparent that there is considerable overlap between the metals that are essential and those that are toxic.

\section{Membrane Carriers Affect the Uptake and Toxicity of Many Metals}

Many of the essential trace elements, the trace elements that are probably essential, and the elements that possibly have essential functions produce significant toxicity (World Health Organization, 1996). It might be anticipated that there are mechanisms to regulate their fate in mammals to maintain sufficient, as well as nontoxic, concentrations. Membrane transport proteins (carriers or channel molecules in the plasma cell membrane) have been identified for most of these metals. Plasma membrane metal transporters may be quite selective, transporting one metal species but not another, due to selective binding sites that recognize specific chemical species. Some examples follow. $\mathrm{Cr}(\mathrm{III})$ is unable to enter cells but $\mathrm{Cr}(\mathrm{VI})$ enters cells through membrane anion transporters (Singh et al., 1998). Many divalent cations including Cd, $\mathrm{Co}, \mathrm{Cu}, \mathrm{Fe}, \mathrm{Mn}, \mathrm{Pb}$ and $\mathrm{Zn}$ are substrates for the divalent metal transporter 1 (DMT-1 also known as DCT-1 or nramp-2) which may mediate their intestinal uptake (Gunshin 
et al., 1997; Picard et al., 2000). Transferrin also moves Fe across membranes (Hentze et al., 2004). It appears that multidrug resistance-associated protein-2 (MRP2) mediates the biliary transport of glutathione complexes of As and cisplatin and perhaps $\mathrm{Cu}, \mathrm{Cd}$ and $\mathrm{Hg}$ (Ballatori, 2002). Cu is also transported by a carrier, hCTR2, that is well conserved across organisms (Zhou and Gitschier, 1997; Lee et al., 2002). Forms of Cr, Mo and Se are structurally similar to sulfate and can serve as substrates for sulfate transporters (Ballatori, 2002). Selenomethionine is transported in the intestine by the same transporter that mediates methionine uptake (Moesgaard and Morrill, 2001). Se(IV) is taken up erythrocytes by an anion-exchange carrier (Suzuki et al., 1998). In addition to serving as a substrate for DMT-1, Zn transport is mediated by plasma membrane importers, hZip1, hZip 2 and ZnT-1 (Ballatori, 2002; Haase and Beyersmann, 2002), members of the cation diffusion facilitator family (Guffanti et al., 2002) and probably other carriers. A classic example of carrier-mediated flux is brain uptake by the large neutral amino acid transporter of the cysteine-methylmercury complex that mimics methionine (Aschner and Clarkson, 1988). These examples, and others in this review, illustrate that carriers can influence the fate and toxicity of specific metal species.

\section{Valence State and Isotope can Influence the Fate and Toxicity of Many Metals}

Many toxic metals have more than one biologically relevant valence state. These include: $\mathrm{Ag}(0, \mathrm{I}$ and II), Am(III, IV, V and VI), As(III and V), Co(II and III), $\mathrm{Cr}(\mathrm{III}$ and VI), $\mathrm{Cu}(0, \mathrm{I}$ and II), $\mathrm{Fe}(0, \mathrm{II}$ and III), $\mathrm{Hg}(0, \mathrm{I}$ and II), Mn(II, III and IV), Mo(II, III, IV and VI), $\mathrm{Ni}(I I$ and IV), $\mathrm{Pu}(\mathrm{III}, \mathrm{IV}, \mathrm{V}$ and $\mathrm{VI}), \mathrm{Sb}(\mathrm{III}$ and $\mathrm{V}), \mathrm{Se}(\mathrm{II}, \mathrm{IV}$ and $\mathrm{VI}), \mathrm{Sn}(\mathrm{II}$ and IV), $\mathrm{Te}(0, \mathrm{II}$, $\mathrm{IV}$ and $\mathrm{VI}), \mathrm{TI}(\mathrm{I}$ and $\mathrm{III}), \mathrm{U}(\mathrm{III}$ and $\mathrm{VI}), \mathrm{V}(\mathrm{IV}$ and $\mathrm{V})$, and $\mathrm{Zn}(0$ and II). Biotransformations 
among biologically relevant valence states and estimates of the relative toxicity of the different valences are shown in the above referenced website. Valence can affect the absorption, distribution, biotransformation, and elimination of a metal and therefore its toxicity. For example, $\mathrm{Cr}(\mathrm{VI})$ is better absorbed than $\mathrm{Cr}(\mathrm{III})$ by the oral and dermal routes (Mertz, 1969; Langård and Norseth, 1979; Rowbotham et al., 2000).

Comparisons have shown that $\mathrm{Sn}(\mathrm{II})$ is better absorbed orally than $\mathrm{Sn}(\mathrm{IV})$ (Hiles, 1974), $\mathrm{U}(\mathrm{VI})$ is better absorbed by inhalation than $\mathrm{U}(\mathrm{IV})$ (Stokinger, 1981; Eidson, 1994) and that $\mathrm{Se}(\mathrm{IV})$ is better absorbed by inhalation than $\mathrm{Se}(0)$ (Medinsky et al., 1981b). Studies in Caco-2 cells, an in vitro model of the gastrointestinal epithelium, revealed that $\mathrm{Fe}$ treatment decreased cellular uptake of $\mathrm{Fe}, \mathrm{Mn}$ and $\mathrm{Zn}$, suggesting these metals may utilize the same cell membrane transporters (Tallkvist et al., 2000). Ingested Fe(II) is absorbed by enterocytes via DMT-1 (Gunshin et al., 1997). DMT-1 mRNA levels in the duodenum increase markedly in response to Fe depletion (Gunshin et al., 2001; Philpott, 2002). It appears that neutral gelatinase-associated lipocalin is another Fe trafficking protein that transports $\mathrm{Fe}(\mathrm{III})$ rather than Fe(II) (Kaplan, 2002). Transferrin in mammals, and ovotransferrin in birds, also show metal valence selectively, transporting Fe(III) into cells, via receptor-mediated endocytosis (Evans and Holbrook, 1975). The valence of a metal can also influence its excretion. $\mathrm{As}(\mathrm{V})$ is excreted more rapidly than As(III) (Hogan and Eagle, 1944). Therefore As(III) is retained to a greater degree than As(V) (Vahter and Norin, 1980; Lindgren et al., 1982; Vahter and Marafante, 1983). The relationships between valence state and absorption do not permit one to predict the relative absorption of two or more metal species based on their relative valences. 
One of the best metals for demonstrating the variation in toxicity resulting from differing valence states is $\mathrm{Hg}$. Ingested elemental $\mathrm{Hg}(\mathrm{Hg}(0))$ is not particularly toxic because of low gastrointestinal absorption (Bornmann et al., 1970). In contrast, inhaled $\mathrm{Hg}(0)$ is almost completely absorbed by the lungs (Berlin et al., 1969b). $\mathrm{Hg}(0)$ is oxidized to $\mathrm{Hg}(\mathrm{II})$ by catalase in erythrocytes (Magos et al., 1978), but not before some of the lipid-soluble $\mathrm{Hg}(0)$ crosses into the CNS (Klaassen, 2001). Absorption of inorganic $\mathrm{Hg}(\mathrm{I})$ and $\mathrm{Hg}(\mathrm{II})$ from the gastrointestinal tract is incomplete, but greater than $\mathrm{Hg}(0)$ (Miettinen, 1973; Sin et al., 1983; Yeoh et al., 1986; Sin et al., 1990). The highest $\mathrm{Hg}(\mathrm{II})$ concentrations are found in the proximal renal tubules, the primary site of toxicity after exposure to inorganic salts and $\mathrm{Hg}(0)$ vapor (Goyer and Clarkson, 2001). Inorganic $\mathrm{Hg}(\mathrm{I})$ and $\mathrm{Hg}(\mathrm{II})$ do not readily cross the blood-brain barrier whereas $\mathrm{Hg}(0)$ and methyl Hg readily do enter the brain by this route (Berlin et al., 1969a; Suzuki, 1969). Thus the major symptoms of organic $\mathrm{Hg}$ toxicity are neurological, including paresthesias, visual disturbances and muscle tremors. Neurotoxicity is more prominent with elemental $\mathrm{Hg}$ than with the inorganic forms. Inhalation of $\mathrm{Hg}$ vapor is the most common cause of $\mathrm{Hg}$ induced acute toxicity, producing chest pain, shortness of breath and renal tubular necrosis. Chronic exposure to lower levels of $\mathrm{Hg}$ vapor produces a toxicity dominated by neurological signs and vasomotor disturbances, the "mad hatter" signs of increased excitability, tremors, and gingivitis (Smith, 1992). For $\mathrm{Hg}$ it is clear that there are distinct toxicities associated with each valence state and organic form. For example, $\mathrm{Hg}(\mathrm{I})$ is not as toxic as $\mathrm{Hg}(\mathrm{II})$, and until relatively recently was found in some skin creams for its antiseptic properties (Klaassen, 2001). The order of general toxic potential is: $\mathrm{CH}_{3} \mathrm{Hg}>$ $\mathrm{Hg}(\mathrm{II})>\mathrm{Hg}(0)>\mathrm{Hg}(\mathrm{I})$. 
Another metal that exhibits contrasting toxicities as a result of different valence states is As. There are two primary families of inorganic As compounds - the arsenites $(\mathrm{As}(\mathrm{III}))$ and arsenates $(\mathrm{As}(\mathrm{V}))$. As(III) is the principal toxic form and tends to accumulate in vivo. Mitochondrial respiration mediated by NAD-linked substrates is inhibited by As(III), due to reaction between the arsenite ion and the dihydrolipoic acid cofactor required for substrate oxidation (Goyer and Clarkson, 2001). With acute As(III) overdose the fundamental lesion is endothelial cellular toxicity. Chronic poisoning is subtle and leads to peripheral distal neuropathy, the most common motor neuropathy. $\mathrm{As}(\mathrm{V})$ competes with phosphate at a co-transporter in renal brush border membranes and in a transport system in the basolateral border of renal cells. The anion exchange transport system in erythrocytes also accepts $\mathrm{As}(\mathrm{V})$ as a phosphate congener (Clarkson, 1993).

While there is much physiological conversion of $\mathrm{As}(\mathrm{V})$ to $\mathrm{As}(\mathrm{III})$, the subsequent metabolic pathway is more complex than previously conceptualized (Hughes, 2002; Aposhian et al., 2003). Oxidative methylation ultimately produces monomethylarsonic acid $(\mathrm{MMA}(\mathrm{V}))$ and dimethylarsinic acid $(\mathrm{DMA}(\mathrm{V}))$, which are less reactive with tissue constituents, less acutely toxic, and less cytotoxic than inorganic forms of As. However, there is evidence that the intermediate metabolites monomethylarsonous acid (MMA(III)) and dimethylarsinous acid (DMA(III)) are more toxic than $\mathrm{As}(\mathrm{V}), \mathrm{As}(\mathrm{III})$ or the analogous $\mathrm{As}(\mathrm{V})$ metabolites (Cohen et al., 2002; Hughes, 2002).

Therefore, As toxicity is a function of 1$)$ chemical form - the $A s(V)$ organic metabolites are less toxic than the inorganic forms; 2) solubility - As(III) is more soluble and toxic than $\mathrm{As}(\mathrm{V})$; 3) valence state - $\mathrm{As}(\mathrm{III})$ is more toxic to the $\mathrm{CNS}$; and 4) duration 
of exposure. At this time the best evidence suggests the order of toxic potential to be: $\operatorname{MMA}(\mathrm{III})>\mathrm{DMA}(\mathrm{III})>\operatorname{As}(\mathrm{III})>\operatorname{As}(\mathrm{V})>\operatorname{MMA}(\mathrm{V})>\mathrm{DMA}(\mathrm{V})$. Thus, while organification appears to render metals such as $\mathrm{Pb}, \mathrm{Hg}$, and $\mathrm{Sn}$ more toxic, no simple generalizations for metalloids like As are evident.

Examples illustrating the influence of valence on elimination are summarized in Table 1. These comparisons are from different studies that used different endpoints. Comparisons should only be made within, not across, studies.

Using $\mathrm{Hg}$ and As as examples, it is clear that different valence states exhibit characteristic patterns of metal toxicity. Could one conclude that valence magnitude directly correlates with severity of toxicity? The evidence does not generally support this, as shown in Table 2. While such a relationship may apply for $\mathrm{Hg}$ where $\mathrm{Hg}(\mathrm{II})$ produces much more toxicity than $\mathrm{Hg}(\mathrm{I})$, this is not true for $\mathrm{As}(\mathrm{III}), \mathrm{Cr}(\mathrm{IV})$ or $\mathrm{Cr}(\mathrm{V})$, or $\mathrm{Mn}(\mathrm{III})$. What can be concluded is that severity of toxicity is dependent on how metal valence states interact with other physiological variables that determine the adverse response. Given the recognized effects of valence state on toxicokinetics, quality risk assessment should incorporate valence state-specific differences in toxicity.

Some metals have more than one biologically relevant isotope, including ${ }^{226} \mathrm{Ra}$ and ${ }^{228} \mathrm{Ra}$; the anthropogenic ${ }^{232} \mathrm{U}$ and ${ }^{233} \mathrm{U}$ and the natural ${ }^{234} \mathrm{U},{ }^{235} \mathrm{U}$ and ${ }^{238} \mathrm{U}$; ${ }^{238} \mathrm{Pu}$ and ${ }^{239} \mathrm{Pu}$; and ${ }^{228} \mathrm{Th},{ }^{230} \mathrm{Th}$ and ${ }^{232} \mathrm{Th}$. The isotope has been reported to affect absorption. For example, ${ }^{238} \mathrm{Pu}$ nitrate and dioxide were more rapidly absorbed in the dog following inhalation exposure than ${ }^{239} \mathrm{Pu}$ nitrate and dioxide, whereas ${ }^{239} \mathrm{Pu}$ nitrate was absorbed by the rat more rapidly than ${ }^{238} \mathrm{Pu}$ nitrate (Morin et al., 1972; Park et al., 
1972; Dagle et al., 1983). A simple relationship between the isotope and toxicity is not evident.

\section{Particle Size can affect Metal Deposition, Uptake and Toxicity}

The size of particles affects their deposition in the lung. Pulmonary introduction of particles $>10 \mu \mathrm{m}$ diameter results in their deposition into the upper airway and usually mucociliary clearance into the gastrointestinal tract. Respirable particles $\sim 5 \mu \mathrm{m}$ diameter enter bronchioles and alveoli. Particles $\sim 0.1 \mu \mathrm{m}$ reach the alveoli, where the surface area is $100 \mathrm{~m}^{2}$, equivalent to a singles tennis court. Particles can be absorbed from the bronchioles and alveoli to enter the bloodstream, avoiding first pass hepatic clearance, as discussed in the Toxicological Profiles on $\mathrm{Cd}, \mathrm{Mn}, \mathrm{Ni}, \mathrm{Pb}$ and TI (ATSDR). Exposure to equivalent masses of an identically deposited substance may not produce the same response if particle sizes differ. For instance, ultrafine particles of Ti dioxide produced a greater inflammatory response in the rat lung than did larger particles (Oberdörster et al., 1994).

\section{Metal-Associated Ligands and Toxicity}

The ligand associated with a metal affects its chemical form, therefore the speciation of the metal. Ligands are atoms, ions or functional groups that bond to one or more central atoms or ions, usually metals, to form a complex. For example, the ligand associated with a metal can affect its solubility which can greatly influence lung absorption and clearance (Rhoads and Sanders, 1985). The associated ligand can also affect absorption from other routes as well as the distribution, biotransformation and 
elimination of a metal. These effects on the metal's fate can influence the adverse effects produced. For example, the absorption, distribution and subsequent toxicity of $\mathrm{Al}$, which only exists in biological systems as $\mathrm{Al}(\mathrm{III})$, is influenced by its associated ligand and the stability of the Al-ligand complex. The predominant ligands and their stability constants have been used to predict the Al species in the calculations described in (Caruso et al., 2005). Intestinal Al absorption is facilitated by citrate (Goyer and Clarkson, 2001). In the absence of a complexing ligand such as citrate, hydrolysis of Al complexes results in sparingly soluble polynuclear species that are less well absorbed. Over $90 \%$ of plasma $\mathrm{Al}$ is bound to transferrin; the remainder is bound to low molecular weight ligands, predominantly citrate (Caruso et al., 2005). Al uptake into the brain is not well defined. One mechanism may involve transferrin, as occurs with receptor-mediated endocytosis of Fe(III) (Roskams and Connor, 1990). Citrate is a good candidate for involvement in brain Al uptake as well (Van Landeghem et al., 1998; Templeton, 1999). Al efflux from the brain probably does not involve transferrin-receptor mediated endocytosis as there are thought to be no available transferrin metal binding sites in brain extracellular fluid to mediate metal efflux by a transferrin-receptor mediated process (Bradbury, 1997). Al citrate appears to be transported out of the brain by mechanisms not involving the transferrin receptor (Yokel, 2001).

Solubility can be influenced by the associated ligand. Solubility can affect absorption. Aqueous solubility enhances absorption from the lung and lipid solubility enhances dermal absorption. Solubility is a chemical property of metals, therefore a factor of metal speciation, which can impact on the adverse response of the metal. For example, following inhalation exposure, soluble forms of a metal enhance systemic 
toxicity whereas respiratory toxicity is more likely from poorly soluble metals (Schlesinger, 1995). To illustrate, Cd from fumes was absorbed to a greater extent than Cd carbonate and Cd from pigments (Rusch et al., 1986; Jakubowski, 2001). The oral bioavailability of soluble $\mathrm{Cr}(\mathrm{VI})$ in potassium chromate appears to be higher than $\mathrm{Cr}(\mathrm{III})$ because if $\mathrm{Cr}(\mathrm{III})$ is not well complexed it precipitates at physiological $\mathrm{pH}$ (Darrie, 2001). However, the conversion of $\mathrm{Cr}(\mathrm{VI})$ by stomach acid to $\mathrm{Cr}(\mathrm{III})$ confounds this (Finley et al., 1997). Also contributing to the superior absorption of $\mathrm{Cr}(\mathrm{VI})$ may be its ability to enter cells by facilitated diffusion mediated by anion exchange and/or sulfate carriers (Wiegand et al., 1985) whereas $\mathrm{Cr}(\mathrm{III})$ cell entry is by passive diffusion and phagocytosis (Figure 2). The more soluble $\mathrm{Cr}(\mathrm{VI})$ salts are also better absorbed through skin than Cr(III), and presumably also by inhalation (Langård and Norseth, 1979). Greater absorption of the more soluble chemical forms of many other metals has been reported, including Ba by inhalation (Einbrodt et al., 1972; Cuddihy et al., 1974) and oral absorption (Johnson and VanTassell, 1991), Ti by the oral route (Schkroeder et al., 1963), Mn after its inhalation (Vitarella et al., 2000; Dorman et al., 2001), Co by the oral route (Barnaby et al., 1968; Hollins and McCullough, 1971; Bailey et al., 1989; AyalaFierro et al., 1999), Ni following inhalation (Benson et al., 1994; Hirano et al., 1994) and oral exposure (Ishimatsu et al., 1995), Pt by the inhalation route (Moore et al., 1975), and As after inhalation and oral exposure (ATSDR). Further information and references to the supporting literature can be found in the web-based database cited above. The greater absorption of the more soluble forms of many metals is thought to contribute to greater toxicity. Therefore one mechanism underlying differences in the toxicokinetics of metal species is their physico-chemical properties. 
Observations concerning metal-associated ligands are largely empirical, so a question is whether one can identify a model to predict metal ion reactivity and metalligand stability. The importance of the associated ligand is examined in more detail below with respect to the toxicity of $\mathrm{Pb}$.

$\mathrm{Pb}$ is a metal with a single prominent valence state (i.e., II) that avidly forms complexes in physiological solutions. Some factors that enhance absorption and distribution have been identified. The major determinant of absorption is the solubility of the $\mathrm{Pb}$ salt, and the process appears to be facilitated diffusion (Goyer and Clarkson, 2001). Transport through an anion exchange channel is a primary means of $\mathrm{Pb}$ entry into cells, and appears to involve a $\mathrm{Pb}$ carbonate anion - for example, $\mathrm{Pb}\left(\mathrm{CO}_{3}\right) \mathrm{Cl}^{-}$ (Simons, 1986). In contrast, $\mathrm{Pb}(\mathrm{II})$ transport across the blood-brain barrier has been hypothesized to be by passive diffusion of $\mathrm{PbOH}^{+}$(Deane and Bradbury, 1990). Notably, free hydrated $\mathrm{Pb}(\mathrm{II})$ appears to stimulate protein kinase $\mathrm{C}$ (Markovac and Goldstein, 1988; Long et al., 1994), to enter neuronal L-type voltage-sensitive $\mathrm{Ca}(\mathrm{II})$ channels (Clarkson, 1993), and may also enter neurons via store-operated Ca(II) channels (Kerper and Hinkle, 1997). Finally, a significant amount of intracellular $\mathrm{Pb}(\mathrm{II})$ is bound to protein in astrocytes, neurons, renal tubular cells, and erythrocytes.

Another mechanism by which the associated ligand can influence toxicokinetics, and therefore toxicodynamics, is by influencing the process that moves metals cross membranes. If the metal-ligand complex is a substrate for carrier-mediated transport, that process will add to the transmembrane flux provided by diffusion. Among the many examples of the impact of the associated ligand on the fate of metals is the greater oral absorption of selenomethionine and selenite than elemental Se, probably due to their 
carrier-mediated uptake (McConnell and Cho, 1965; Anundi et al., 1984). Cd bound to high molecular weight circulating proteins is mainly trapped by the liver whereas $\mathrm{Cd}$ bound to low molecular weight species, such as metallothionein, distributes into the kidney and appears in the urine (Jakubowski, 2001). $\mathrm{CH}_{3} \mathrm{Hg}$ forms a complex with $\mathrm{L}-$ cysteine that resembles methionine and is transported into the brain by the L-type neutral amino acid carrier (Aschner and Clarkson, 1989). Organic forms of As are excreted more rapidly than inorganic forms (Coulson and al, 1935; Overby and Frost, 1962; Morgareidge, 1963). The several-hundred fold greater concentration of As in bile than plasma (Klaassen, 1974) may be mediated by multi-drug resistance protein 2 transport of glutathione-As complexes (Ballatori, 2002). The relationship between metalassociated ligands and toxicity has also been examined for $\mathrm{Mn}(\mathrm{II})$, and some important toxicokinetic factors identified. Approximately $87 \%$ of plasma $\mathrm{Mn}(\mathrm{II})$ is bound to albumin with most of the balance bound to low-molecular-mass ligands; most $\mathrm{Mn}(\mathrm{III})$ is bound to transferrin (Aschner, 2000). Mn(II) can cross the blood-brain barrier as the citrate, the free divalent ion, or bound to transferrin (Crossgrove et al., 2003), occurring via transferrin receptor-mediated endocytosis and other transport processes (Crossgrove and Yokel, in press). Efflux from the brain appears to occur by simple diffusion (Yokel et al., 2003). Astrocyte toxicity correlated with the Mn-associated ligand. Solubility of the $\mathrm{Mn}$ (II) salt and intracellular $\mathrm{Mn}$ (II) concentration are the major determinants. The order of toxic potential was $\mathrm{MnCl}_{2}>\mathrm{MnSO}_{4}>\mathrm{MnPO}_{4}$ (Erikson et al., 2002). $\mathrm{Mn}$ (II) accumulation in astrocytes and uptake across the blood-brain barrier appear to occur via one or more transport processes shared with $\mathrm{Ca}(\mathrm{II})$ (Aschner et al., 1992; 
Crossgrove and Yokel, in press). Thus, it is clear that the metal-associated ligand can profoundly affect bioavailability and the effects of exposure.

\section{Organic Versus Inorganic Metal Species}

Comparisons of the relative absorption of inorganic versus organic metal species generally suggest greater absorption of organic forms. This is illustrated with $\mathrm{Hg}$. Organic mercurials, such as $\mathrm{CH}_{3} \mathrm{Hg}$, are almost completely absorbed from the gastrointestinal tract and are well absorbed following dermal exposure (Swensson, 1952; Joselow et al., 1972; Nordberg and Skerfving, 1972). These Hg species are widely distributed throughout the body because of their lipophilic nature (Klaassen, 2001). In contrast, the oral bioavailability of inorganic $\mathrm{Hg}$ species is considerably lower (Sollman and Schreiber, 1936; Rahola et al., 1973). Organotins are often better absorbed than inorganic Sn species but this varies considerably with the organotin presumably by all routes of exposure (Heath, 1963; Brüggemann et al., 1964; Bridges et al., 1967; Mazaev et al., 1976; Winship, 1988). Organolead compounds are better absorbed by the dermal route than inorganic Pb species (Verity, 1995). Organic Se is better absorbed orally than inorganic forms (Thomson et al., 1975; Bopp et al., 1982) (Cummins and Kimura, 1971; Cary et al., 1973; Medinsky et al., 1981a). An exception to the greater absorption of organic than inorganic species may be As (Bettley and O'Shea, 1975; Munro, 1976; Crecelius, 1977; Charbonneau et al., 1978; Pomroy et al., 1980; Vahter and Norin, 1980; Marafante et al., 1981; Tam et al., 1982; Vahter and Marafante, 1983; Marafante et al., 1984). Another exception is the ability of some amino acids to decrease oral Co, $\mathrm{Cu}$ and $\mathrm{Ni}$ absorption (Taylor, 1962; Baker and Czarnecki- 
Maulden, 1987; Johnson and Lee, 1988; Pott et al., 1994; Templeton et al., 2000), presumably by chelation through formation of a coordination complex. In contrast, some metals bind to specific amino acids forming species that are substrates for uptake carriers. For example, this facilitates the oral absorption of Cu (Wapnir and Stiel, 1986) and distribution to the brain of methylmercury (Aschner and Clarkson, 1988).

Distribution, biotransformation and excretion of organic and inorganic metal forms often differ as well. The greater toxicity of organic species of several metals, including $\mathrm{Pb}$ and $\mathrm{Bi}$, has been attributed to greater penetration of the blood-brain barrier (Clarkson, 1979). Metallothionein-bound Cd distributed differently than ionic Cd species. The CdMT complex is transported to the kidney, filtered, and reabsorbed into the proximal tubule via a mechanism involving receptor-mediated endocytosis (Foulkes, 1978; Squibb et al., 1984; Dudley et al., 1985; Dorian et al., 1992). Some organic Se species are retained in tissue longer than inorganic species, presumably due to incorporation into proteins (Sternberg and Imbach, 1967; McConnell and Hoffman, 1972; Hsieh and Ganther, 1975). This also results in lower rates of organic, than inorganic, Se excretion (Mangels et al., 1990). Protein-bound metals are not cleared by the kidney as rapidly as small molecular weight non-protein bound species. The ratio of renal to fecal metal elimination is also influenced by the species of As. Whereas the ratio is $\sim 1$ for organic As, more inorganic As is excreted in feces than in urine (Coulson and al, 1935; Overby and Frost, 1962; Morgareidge, 1963). Ni carbonyl is excreted by the lungs. After it has been degraded, the metabolites appear in the urine (Sunderman and Selin, 1968; Kasprzak and Sunderman, 1969), as also occurs after Ni chloride and sulfite administration (English et al., 1981; Carvalho and Ziemer, 1982; Medinsky et al., 1987). 
More illustrations of the differences in metal toxicokinetics of organic versus inorganic metals can be found in the toxicokinetics database mentioned above.

\section{Biotransformation Can Change Metal Fate and Toxicity}

Biotransformation can have a profound impact on toxicokinetics and toxicodynamics. The resultant metal species may have a different ligand and/or valence state, changing absorption and thereby toxicity. For example, dissolution by gastric juice has been suggested to increase $\mathrm{Ag}, \mathrm{Al}, \mathrm{B}, \mathrm{Ba}, \mathrm{Be}$ and $\mathrm{Zr}$ solubility and potentially absorption (Smith and Carson, 1977; Stokinger, 1981; Johnson and VanTassell, 1991; Reiber et al., 1995) (Culver et al., 2001; Mroz et al., 2001), although Zr and Al have also been suggested to subsequently become less soluble at the higher $\mathrm{pH}$ of the intestine (Stokinger, 1981; Reiber et al., 1995). In the absence of a complexing ligand such as citrate, hydrolysis of $\mathrm{Al}(\mathrm{III})$ complexes results in sparingly soluble polynuclear species that result in reduced absorption. Dietary phytates produce insoluble, non-absorbed complexes with $\mathrm{Cu}, \mathrm{Fe}, \mathrm{Mn}$ and $\mathrm{Zn}$ at the gut $\mathrm{pH}$ (Windisch, 2002). Phytates similarly decrease $\mathrm{Cr}(\mathrm{III})$ absorption but oxalate enhances it, by preventing formation of insoluble Cr oxides (Chen et al., 1973).

Biotransformation can also affect metal distribution, elimination and toxicity. Excellent examples are $\mathrm{Hg}$ and $\mathrm{As} . \mathrm{Hg}(0)$ and organomercurials, such as methyl, ethyl (in thimerosal, sodium ethylmercurithiosalicylate) and phenyl mercury, can be converted to inorganic $\mathrm{Hg}(\mathrm{II})$ in nearly all organs, including the brain. Redistribution of inorganic $\mathrm{Hg}$ (II) out of the brain and other organs is slow (Magos et al., 1978; WHO, 1990, 1991; Foulkes, 2001).The prolonged residence time in the brain is thought to contribute to $\mathrm{Hg}$ 
toxicity to astrocytes and microglia (Charleston et al., 1996). A substantial portion of As $(\mathrm{V})$ is rapidly reduced to $\mathrm{As}(\mathrm{III})$ in the body in association with thiol oxidation (Abernathy et al., 1999). As noted in the above discussion on how valence state and isotope can influence metal fate and toxicity, $\mathrm{As}(\mathrm{III})$ is more extensively retained than As(V). There is also in vivo interconversion of V(IV) and V(V) (Rydzynski, 2001); oxidation of $\mathrm{Mn}$ (II) and $\mathrm{Fe}(\mathrm{II})$ to $\mathrm{Mn}(\mathrm{III})$ and $\mathrm{Fe}(\mathrm{III})$ (Gibbons et al., 1976; Kono et al., 1976; Ezra et al., 1984; Archibald and Tyree, 1987); and reduction of $\mathrm{Cr}(\mathrm{VI})$, and $\mathrm{Pt}(\mathrm{IV})$ to $\mathrm{Cr}(\mathrm{III})$, and $\mathrm{Pt}$ (II) (De Flora and al, 1986; Petrilli et al., 1986; De Flora and al, 1989; De Flora et al., 1989; Zhong et al., 1997). Cr(VI), being unstable in vivo, rapidly reduces to $\operatorname{Cr}(\mathrm{V})$ which is labile and coverts to $\mathrm{Cr}(\mathrm{IV})$ and ultimately to $\mathrm{Cr}(\mathrm{III})$, which is quite stable due to its complexation with DNA and proteins (Kasprzak, 1991). On the other hand, there are many metals with completely filled inner electronic orbitals that do not readily undergo in vivo biotransformation among valence states, such as $\mathrm{Al}, \mathrm{Pb}, \mathrm{Sn}, \mathrm{TI}$ and $\mathrm{Zn}$.

There are examples where valence changes impact distribution (the rates of cell entry of $\mathrm{V}, \mathrm{Fe}$ and $\mathrm{Cr}$ and the protein to which Mn binds) (Gibbons et al., 1976; Danielsson et al., 1982; Langård, 1982; Harris et al., 1984; Templeton et al., 2000) and elimination (the clearance of $\mathrm{Mn}$ and $\mathrm{Cr}$ ) (Gibbons et al., 1976; Norseth et al., 1982). Be and Th form insoluble colloids and Gd forms insoluble carbonate and phosphate precipitates in blood that are then taken up the reticuloendothelial cells (Clarkson, 1979; Stokinger, 1981; Dean et al., 1988). Ag precipitates and is then transformed into complexes or elemental metal that accumulates in the skin, producing a blue-gray discoloration (Danscher, 1981). Cd binds to metallothionein and U binds to bicarbonate 
but the free metals are released in the kidney, producing nephrotoxicity (Bassett et al., 1948; Cherian and Shaikh, 1975; Squibb and Fowler, 1984). Tetraalkyl tins are converted to highly toxic trialkyl derivatives (Stoner et al., 1955). Tetraalkyl Pb is converted to tri-, dialkyl- and to some extent inorganic $\mathrm{Pb}$ (Cremer, 1965). Se and $\mathrm{Te}$ are dimethylated, in a detoxification pathway, to species that are exhaled, producing a characteristic garlic breath (McConnell and Portman, 1952; Taylor, 1996). Organic species of elements are generally excreted faster than inorganic forms (Apostoli, 1999). Many more examples illustrating these points are in the above mentioned database.

Biotransformation may be mediated by non-enzymatic as well as enzymatic processes. For example, $\mathrm{Cr}(\mathrm{VI})$ can be reduced non-enzymatically by glutathione to the more toxic $\mathrm{Cr}(\mathrm{III})$ (Kortenkamp et al., 1989). It seems that $\mathrm{Cr}(\mathrm{VI})$ can also be reduced enzymatically by glutathione reductase (Gunaratnam and Grant, 2001).

The rates of non-enzymatic and enzymatic biotransformation processes can influence whether biotransformation occurs within the residence time of the metal species in vivo. This is described in (Caruso et al., 2005). For example, the mean residence time of water in $\mathrm{Al}\left(\mathrm{H}_{2} \mathrm{O}\right)_{6}{ }^{3+}$ is $\sim 1$ second, the complexation half-life for $\mathrm{Al}\left(\mathrm{H}_{2} \mathrm{O}\right)_{6}{ }^{3+}$ by citrate is $\sim 1$ to 2 minutes and by fulvic acid 7 to 115 seconds (LopezQuintela et al., 1984; Plankey and Patterson, 1987; Burgess, 1992). The exchange halflife of Al from the Al-fulvic acid complex to an Al-Chelex 100 complex is $\sim 4$ to 20 minutes at the weaker and $\sim 2$ to 15 hours at the stronger Al binding site (Sekaly et al., 1999). The latter exceeds the initial half-life of $A l$ in the mammal (Wilhelm et al., 1990). Thus, equilibrium among Al species may not occur in vivo before most $\mathrm{Al}$ is eliminated. 


\section{Models to Predict Toxicity that Incorporate Speciation}

Models have been developed for aquatic toxicology to predict the impact of metal speciation on the toxic response. The most extensively studied system is the free-ion activity model (FIAM) which assumes that simple ionic species interact with binding sites on the cell surface. This model postulates that the biological response elicited by a dissolved cationic trace metal is a function of the free metal ion concentration (Morel, 1983). The toxic response of aquatic organisms generally relates to the free ion concentration. Examples of metals that conform to this model include $\mathrm{Cd}, \mathrm{Cu}, \mathrm{Fe}, \mathrm{Mn}$, $\mathrm{Ni}, \mathrm{Pb}$ and $\mathrm{Zn}$ (Campbell, 1995). There are exceptions. For example, toxicity to green alga was not proportional to the free Al concentration (Parent et al., 1996). It was thought that the Al complexing ligand (fulvic acid) interacted with alga to modulate the $\mathrm{Al}$ response. The FIAM is further limited by the observation that the $\%$ of free ions in solution in the environment is generally less than $2 \%$ (Donard, 2001) and often cannot be determined analytically. In seawater most $\mathrm{Ni}, \mathrm{Mn}(\mathrm{II}), \mathrm{Zn}, \mathrm{Co}(\mathrm{II})$ and $\mathrm{Fe}(\mathrm{II})$ are present as free aquo ions. However, $\mathrm{Cd}, \mathrm{Cu}(\mathrm{I}), \mathrm{Ag}(\mathrm{I})$ and $\mathrm{Hg}(\mathrm{II})$ complex with chloride $(\mathrm{Cl})$; $\mathrm{Cu}(\mathrm{II})$ and $\mathrm{Pb}(\mathrm{II})$ with carbonate; and $\mathrm{Fe}(\mathrm{III})$ and $\mathrm{Al}$ with hydroxide ions (Byrne et al., 1988).

The biotic ligand model (BLM), which also predicts the impact of speciation on the adverse response, has generated considerable interest for its potential to perform risk assessment of metals in aquatic environments (see (Paquin et al., 2002) and the 21 companion papers in the same journal issue). This is a chemical equilibrium-based model founded on the concept that metal binding to defined sites (biotic ligands) at the point of action, typically the cell surface, is associated with acute toxicity. It recognizes 
that the interaction between the metal's chemistry and the physiology of the target organism affects the adverse response, and therefore, risk assessment. It differs from the FIAM in its emphasis on the biotic ligand, the site of toxicity of the organism. It assumes that there is competition for binding to the biological ligand among the cationic metal and dissolved organic matter; inorganic ligands such as hydroxides, chlorides and carbonates; and competing cations such as $\mathrm{Na}^{+}, \mathrm{Ca}(\mathrm{II}), \mathrm{Mg}(\mathrm{II})$ and $\mathrm{H}^{+}$ions. This model recognizes that metal speciation affects metal binding to sites of toxicity. Chemical considerations for the FIAM, BLM and other models are discussed in (Caruso et al., 2005). Reasonable agreement has been found between experimental toxicity endpoints and those predicted by the BLM. However, most studies have been conducted using metal concentrations in excess of those seen in the environment (Batley, 2003). The BLM has been primarily used to predict toxicity at 96 hours after 3 or 24 hour gill binding assay exposures because they are more convenient to conduct and provide more consistent data than longer exposures (Niyogi and Wood, 2003). Application of the BLM to chronic exposure has been performed (Niyogi and Wood, 2003), and provides guidance to further development of this model. There is an absence of similar models that incorporate the many aspects of metal speciation for mammalian organisms.

Although models have been developed for toxicity-inducing metals in mammalian organisms, they have seldom considered metal speciation. A noteworthy model to predict metal ion reactivity and metal-ligand stability is the classification system proposed by Nieboer and colleagues (Nieboer and Richardson, 1980; Nieboer et al., 1999). This system was developed from fundamental properties of metal ions. It is based upon electronegativity, the tendency for the metal atom to become negatively 
charged, and coordination number, the number of sites at which complexed ligands are attached to a metal ion. To classify metal atoms according to their ability to form covalent bonds the index $\left(\chi_{\mathrm{m}}\right)^{2} r$ is utilized, where $\chi_{\mathrm{m}}$ is the electronegativity and $r$ is the ionic radius of the species with the most common coordination number. This index is interpreted as comparing valence orbital energy with ionic energy, and thus reflects the relative ability to form covalent versus ionic bonds. That is, it is a covalent index. A second index was devised as $z^{2} / r$ to represent ionic interactions, where $z$ is the ion charge and $r$ is defined as above.

The graph of these two values for ions of 36 metals and two metalloids is shown in Figure 3. All groups of the periodic chart containing metals are represented, as are all periods of the chart with the exception of the actinides. With this plot Nieboer and Richardson (1980) also separated metal and metalloid ions into three groups, reproducing the traditional groupings of Class A ('hard' acids, oxygen donor-atom seekers), Class B ('soft' acids, nitrogen/sulfur donor-atom seekers), and intermediate metal ions which display ambivalent affinity for donor-atom types (Hancock and Martell, 1996). The purpose of this classification system was to predict metal-ligand stability and toxicity based on metal ion properties.

For a fixed value of the ionic index in Figure 3, toxicity generally increases with increasing magnitude of the covalent index. For example, $\mathrm{Hg}(\mathrm{II})$ produces more toxicity than $\mathrm{Ca}(\mathrm{II})$. Conversely, for a fixed value of the covalent index, toxicity generally increases with increasing magnitude of the ionic index. For instance, As(III) produces more toxicity than $\mathrm{Cu}(\mathrm{II})$. In addition, for a fixed value of the covalent index, stability with nearly all ligands correlates positively with the ionic index. Similarly, for a fixed 
value of the ionic index, stability generally increases with increasing values of the covalent index. For example, $\mathrm{Pb}$ (II) functionally displaces $\mathrm{Ca}$ (II) in neurons by impeding $\mathrm{Ca}$ (II) entry through membrane voltage-sensitive channels (Suszkiw et al., 1984) and exhibiting greater potency to activate $\mathrm{Ca}(\mathrm{II})$-dependent enzymes and proteins (Shao and Suszkiw, 1991; Long et al., 1994; Kern et al., 2000) Cd(II) has a similar action on voltage-sensitive $\mathrm{Ca}$ (II) channels. Thus, this model suggests that increased metalligand stability results in increased toxicity.

This system is based on general trends in fundamental properties of metal ions, and has evident limitations. Nonetheless, it is an attempt to bring organization to the knowledge of metal-ligand associations in order to provide predictive value for toxicity. Like the FIAM and BLM, it is a laudable step in the right direction. An analogous system for metal-ligand stability based on ligand ('hard'/'soft' base) properties might also be useful.

Speciation information has seen only limited application in physiologically-based models of the kinetics of metals. A model for $\mathrm{Cr}$ has parallel absorption and disposition schemes for $\mathrm{Cr}(\mathrm{III})$ and $\mathrm{Cr}(\mathrm{VI})$, recognizing the importance of valence on the kinetics and toxicity of $\mathrm{Cr}$ (O'Flaherty, 1996). However, these models have largely ignored speciation issues and have only addressed 'bulk movement' of metals.

Similarly, although the importance of speciation has been recognized in epidemiology studies with Al (Gauthier et al., 2000), Hg (Vahter et al., 2000) and Ni (Teaf et al., 2004), the number of epidemiology studies incorporating speciation as a variable is quite limited. 


\section{Risk Assessment Considerations for Essential and Toxic Metals}

Risk assessment can be defined as a characterization of the potential adverse health effects of human exposure to environmental hazards. Steps in risk assessment include a description of potential adverse health effects associated with chemical exposure, extrapolation of results to estimate the extent of human health effects under certain conditions of exposure, and uncertainty characterization (Williams and Paustenbach, 2002). A comprehensive review of regulatory limits set for metals is beyond the scope of this paper; however, important exposure limits include those set for occupational (e.g., TLV) or environmental (e.g., Reference Doses (RfDs) and Reference Concentrations (RfCs)) exposures.

A special challenge for toxicologists is the risk assessment of metals that are essential and toxic. The dose-response curve for these nutrients is U-shaped where deficiency or abnormally high exposures can result in adverse effects (Olin, 1998). Essential metals are obtained from the diet and are often under tight gastrointestinal and hepatobiliary control. Oral toxicity from most essential metals occurs under high dose conditions when these normal homeostatic pathways are overwhelmed. For example, acute Fe poisoning occurs when receptor-dependent processes are saturated and ingested Fe is passively absorbed down concentration gradients (Mills and Curry, 1994). Poisoning may also result from exposure to a more toxic form of the metal, such as a more toxic valence state (e.g., $\mathrm{Cr}(\mathrm{VI})$ vs. $\mathrm{Cr}(\mathrm{III}))$ or a more bioavailable form.

Cr provides a good example to highlight key issues related to risk assessment of an essential and toxic metal. $\mathrm{Cr}$ speciation determines its essentiality and carcinogenicity (Katz, 1991). It occurs primarily as $\operatorname{Cr}(\mathrm{III})$, which is the most stable form, 
as well as $\mathrm{Cr}(\mathrm{VI})$. Elemental $\operatorname{Cr}(0)$ does not occur naturally. $\mathrm{Cr}(\mathrm{III})$ is an essential trace metal that improves glucose tolerance (Kobla and Volpe, 2000) and is required for the metabolism of insulin (Katz, 1991; Rowbotham et al., 2000). $\mathrm{Cr}$ (III) is typically insoluble in water, is poorly absorbed from the gastrointestinal tract, and has low oral toxicity. $\mathrm{Cr}(\mathrm{III})$ forms stable complexes with glutathione, ascorbic acid, and other ligands (Yuann et al., 1999; Gaggelli et al., 2002). Cellular uptake of $\operatorname{Cr}($ III) is low (Figure 2), and it is not mutagenic (De Flora et al., 1990). Likewise, there is little or no evidence that $\mathrm{Cr}(\mathrm{III})$ compounds are carcinogenic in experimental animals or humans (Katz and Salem, 1993).

In contrast, $\mathrm{Cr}(\mathrm{VI})$, including chromate $\left(\mathrm{CrO}_{4}^{2-}\right)$ and dichromate $\left(\mathrm{Cr}_{2} \mathrm{O}_{7}^{2-}\right)$ species, represent anthropogenic forms of $\mathrm{Cr}$. These ions are water soluble and are powerful oxidizing agents. When ingested, $\mathrm{Cr}(\mathrm{VI})$ can be reduced by stomach acids to the less toxic $\operatorname{Cr}(I I I)$ form (De Flora et al., 1987; Finley et al., 1997). Acidic drinks (e.g., lemonade, coffee) can promote $\mathrm{Cr}(\mathrm{VI})$ reduction. Reduction of $\mathrm{Cr}(\mathrm{VI})$ to $\mathrm{Cr}(\mathrm{III})$ is an important factor when considering the risk associated with $\mathrm{Cr}$ ingestion. Indeed, there is little data to support the notion that ingestion of $\mathrm{Cr}(\mathrm{VI})$ is associated with cancer. Scientific evidence suggests $\mathrm{Cr}(\mathrm{VI})$ is not carcinogenic in humans via the oral route at permissible drinking-water concentrations (Kerger et al., 1996; Proctor et al., 2002; Paustenbach et al., 2003).

Inhaled particulate forms of $\mathrm{Cr}(\mathrm{VI})$ produce respiratory tract toxicity including lung and nasal cancers. Clinical signs associated with $\mathrm{Cr}(\mathrm{VI})$ inhalation include bronchial asthma, mucosal ulceration, and perforated nasal septum (Feron et al., 2001). Sinonasal and lung cancers have also been observed in people exposed to relatively 
insoluble forms of $\mathrm{Cr}(\mathrm{VI})$ (Feron et al., 2001). $\mathrm{Cr}(\mathrm{VI})$ enters cells through membrane anion (sulfate/phosphate) transporters where it is subsequently reduced to transient $\mathrm{Cr}(\mathrm{V})$ and more stable $\mathrm{Cr}(\mathrm{III})$ forms (O'Brien et al., 2003). $\mathrm{Cr}(\mathrm{III})$ and $\mathrm{Cr}(\mathrm{V})$ can covalently interact with nucleic acids and other macromolecules (Singh et al., 1998). $\mathrm{Cr}(\mathrm{III}), \mathrm{Cr}(\mathrm{IV})$, and $\mathrm{Cr}(\mathrm{V})$ can react with DNA and induce DNA oxidation and genotoxicity (O'Brien et al., 2003). Cr provides a clear example where metal speciation must be accounted for in the risk assessment process.

Toxicity from essential metals can also occur when normal homeostatic control mechanisms are bypassed. For example, inhalation exposure can result in portal of entry or systemic effects. Inhalation portal of entry effects relate to nasal or pulmonary actions. Rhinitis and nasal septum perforations are associated with exposure to $\mathrm{Cr}(\mathrm{VI})$ and As(III) (Sunderman, 2001). Nasal irrigation of Zn sulfate is associated with olfactory epithelial degeneration, hyposmia, and anosmia (Cancalon, 1982; Sunderman, 2001). Systemic toxicity can also occur from inhalation exposure. Metal fume fever is a welldocumented acute respiratory disease observed in welders and others who inhale ultrafine particles of essential and possibly essential metals (e.g., $\mathrm{Cu}, \mathrm{Mn}, \mathrm{Ni}, \mathrm{V}$, or $\mathrm{Zn}$ ) as well as nonessential metals (e.g., Al, Be, Cd) (Gordon and Fine, 1993). Systemic toxicity is not confined to the lung. Inhalation of $\mathrm{Fe}$ and Mn provide prime examples where neurotoxicity can occur.

Toxicity can occur following parenteral injection. For example, individuals receiving total parenteral nutrition (TPN) were found to be at risk for Mn neurotoxicity. As with other forms of $\mathrm{Mn}$ poisoning, these patients developed elevated serum $\mathrm{Mn}$, they had symmetrical high intensity magnetic resonance imaging (MRI) lesions in the globus 
pallidus consistent with $\mathrm{Mn}$ accumulation at this site, and they developed characteristic psychiatric symptoms and clinical signs of Mn-induced neurotoxicity (Takagi et al., 2002). Withdrawal from the TPN supplement significantly decreased blood and brain Mn levels (Kafritsa et al., 1998; Bertinet et al., 2000). Dermal toxicity can be a concern as well (Kirchner, 2002). Exposure to essential as well as non-essential metals, such as $\mathrm{Au}, \mathrm{Co}, \mathrm{Cr}$ and $\mathrm{Ni}$, can produce contact dermatitis.

Recommended Dietary Allowances (RDAs) or Acceptable Daily Intakes (ADIs) are developed for essential metals. Uncertainty factors used by the nutrition and toxicology communities to set exposure guidelines for essential metals are not shared. In particular, toxicity exposure limits (e.g., RfDs) typically rely on animal data and incorporate uncertainty factors to account for interspecies differences in sensitivity. Most RDAs are based on human data, thus no additional uncertainty factors are needed to account for extrapolation of animal data to human risk assessment. The US EPA also uses a larger uncertainty factor (i.e., up to 10) to describe intraspecies differences than those used by nutritionists to derive acceptable daily intakes (Mertz, 1995; Olin, 1998). These disparate approaches can result in overlap between intakes deemed necessary with those considered potentially toxic (Olin, 1998; Goldhaber, 2003). For example, the World Health Organization (WHO, 1973) concluded that consumption of 8-9 mg Mn/day is "perfectly safe" while the current Reference Dose for Chronic Oral Exposure (RfD) is $10 \mathrm{mg} \mathrm{Mn/day.} \mathrm{The} \mathrm{tolerable} \mathrm{upper} \mathrm{intake} \mathrm{level} \mathrm{(UL),} \mathrm{which} \mathrm{is} \mathrm{considered} \mathrm{the} \mathrm{highest}$ level of daily nutrient intake that is likely to pose no risk of adverse health effects to almost all individuals in the general population, set for Se and $\mathrm{Zn}$ are lower than the current RfD values for these essential nutrients (Goldhaber, 2003). Most nutritional 
levels do not consider speciation despite the wealth of information indicating that valence state and ligand binding dramatically alter the bioavailability of essential metals.

\section{Conclusions}

In this review the relationships between metal speciation, toxicokinetics and toxicodynamics have been examined, focusing particular attention on the factors of valence state, metal-associated ligands and biotransformation. Examples of speciationdependent induced toxicity have been reviewed. An attempt has been made to develop useful generalizations relative to these factors. Among these generalizations it is evident that different metal valence states exhibit characteristic patterns of toxicity, and that the magnitude of the valence state does not correlate with the severity of the adverse response. Moreover, organic metal species are not always more toxic than inorganic forms of the same metal. Furthermore, the nature of the metal-associated ligand can profoundly affect metal ion toxicokinetics and exposure effects. As a result of this latter observation, a published classification system based on metal properties has been proposed to have predictive value related to toxicity.

Evaluation of this system indicated that the severity of the adverse response was generally related to the stability of the metal-ligand complex. Thus, this model might be

utilized to link metal speciation with human health risk assessment. Models have been developed for aquatic toxicology that focus on the free-ion activity and the interaction between metal and site of action of toxicity of the organism. Comparable models have not been developed for mammalian systems. 


\section{REFERENCES}

Abdallah, A., and Saif, M. 1962. Tracer studies with antimony-124 in man. In Bilharziasis, Ciba Foundation Symposium (G. E. W. Wolstenholme and M. O'Connor, eds.), pp. 287-309. J. and A. Churchill (London) Little, Brown (Boston), London.

Abernathy, C. O., Liu, Y. P., Longfellow, D., Aposhian, H. V., Beck, B., Fowler, B., Goyer, R., Menzer, R., Rossman, T., Thompson, C., and Waalkes, M. 1999. Arsenic: health effects, mechanisms of actions, and research issues. Environ. Health Perspect. 107, 593-597.

Anundi, I., Hogberg, J., and Stahl, A. 1984. Absorption of selenite in the rat small intestine: interactions with glutathione. Acta Pharmacol. Toxicol. (Copenhagen). 54, 273-277.

Aposhian, H. V., Zakharyan, R. A., Avram, M. D., Kopplin, M. J., and Wollenberg, M. L. 2003. Oxidation and detoxification of trivalent arsenic species. Toxicol. Appl. Pharmacol. 193, 1-8.

Apostoli, P. 1999. The role of element speciaion in environmental and occupational medicine. Fresenius J. Anal. Chem. 363, 499-504.

Archibald, F. S., and Tyree, C. 1987. Manganese poisoning and the attack of trivalent manganese upon catecholamines. Arch. Biochem. Biophys. 256, 638-650.

Aschner, M. 2000. Manganese: brain transport and emerging research needs. Environ. Health Perspect. 108, 429-432.

Aschner, M., and Clarkson, T. W. 1988. Uptake of methylmercury in the rat brain: effects of amino acids. Brain Res. 462, 31-39. 
Aschner, M., and Clarkson, T. W. 1989. Methyl mercury uptake across bovine brain capillary endothelial cells in vitro: the role of amino acids. Pharmacol. Toxicol. 64, 293-297.

Aschner, M., Gannon, M., and Kimelberg, H. K. 1992. Manganese uptake and efflux in cultured rat astrocytes. J. Neurochem. 58, 730-735.

ATSDR. Toxicological Profiles. Agency for Toxic Substances and Disease Registry, Public Health Service, U.S. Department of Health and Human Services. These are available at: http://www.atsdr.cdc.gov/toxprofiles/tp22.html.

Ayala-Fierro, F., Firriolo, J. M., and Carter, D. E. 1999. Disposition, toxicity, and intestinal absorption of cobaltous chloride in male Fischer 344 rats. J. Toxicol. Environ. Health. 56, 571-591.

Bailey, M. R., Kreyling, W. G., Andre, S., Batchelor, A. L., Collier, C. G., Drosselmeyer, E., Ferron, G. A., Foster, P., Haider, B., Hodgson, A., Masse, R., Metivier, H., Morgan, A., Muller, H. L., Patrick, G., Pearman, I., Pickering, S., Ramsden, D., Stirling, C., and Talbot, R. J. 1989. An interspecies comparision of the lung clearance of inhaled monodisperse cobalt oxide. Part 1. Objective and summary results. J. Aerosol Sci. 20, 169-188.

Baker, D. H., and Czarnecki-Maulden, G. L. 1987. Pharmacologic role of cysteine in ameliorating or exacerbating mineral toxicities. J. Nutr. 117, 1003-1010.

Ballatori, N. 2002. Transport of toxic metals by molecular mimicry. Environ. Health Perspect. 110 Suppl 5, 689-694.

Barnaby, C. F., Smith, T., and Thompson, B. D. 1968. Dosimetry of the radioisotopes of cobalt. Physics Med. Biol. 13, 421-433. 
Bassett, S. H., Frankel, A., Cedars, N., Van Alstine, H., Waterhouse, C., and Cusson, K. 1948. The excretion of hexavalent uranium following intravenous administration. II. Studies on human subjects. Univ. of Rochester: U.S. Atomic Energy Commission Report Report UR-37 (Advisory Committee on human radiation experiments No. CON-030795-A-1). 54 pages. University of Rochester, Rochester.

Batley, G. 2003. Regulation of toxicants in the Australian environment. Aust. J. Chem. $56,141-147$.

Benson, J. M., Barr, E. B., Bechtold, W. E., Cheng, Y. S., Dunnick, J. K., Eastin, W. E., Hobbs, C. H., Kennedy, C. H., and Maples, K. R. 1994. Fate of inhaled nickel oxide and nickel subsulfide in F344/N rats. Inhal. Toxicol. 6, 167-183.

Berlin, M., Fazackerley, J., and Nordberg, G. 1969a. The uptake of mercury in the brains of mammals exposed to mercury vapor and to mercuric salts. Arch. Environ. Health. 18, 719-729.

Berlin, M. H., Nordberg, G. F., and Serenius, F. 1969b. On the site and mechanism of mercury vapor resorption in the lung. A study in the guinea pig using mercuric nitrate Hg 203. Arch. Environ. Health. 18, 42-50.

Bernhard, M., Brinckman, F., and Sadler, P. 1986. The importance of chemical speciation in environmental processes. Springer Verlag, Berlin.

Bertinet, D. B., Tinivella, M., Balzola, F. A., de Francesco, A., Davini, O., Rizzo, L., Massarenti, P., Leonardi, M. A., and Balzola, F. 2000. Brain manganese deposition and blood levels in patients undergoing home parenteral nutrition. J. Parenter. Enteral. Nutr. 24, 223-227. 
Bettley, F. R., and O'Shea, J. A. 1975. The absorption of arsenic and its relation to carcinoma. Br. J. Dermatol. 92, 563-568.

Bingham, E., Cohrssen, B., and Powell, C. H., eds. 2001. Patty's Toxicology. John Wiley \& Sons, Inc., New York.

Boisset, M. 2000. Environmental contamination by trace elements. Consequences for animal and human health. Comp. Rend. L'Acad. d'Agric. France. 86, 49-65.

Bopp, B. A., Sonders, R. C., and Kesterson, J. W. 1982. Metabolic fate of selected selenium compounds in laboratory animals and man. Drug Metab. Rev. 13, 271-318.

Bornmann, G., Henke, G., Alfes, H., and Mollmann, H. 1970. Intestinal absorption of metallic mercury. Arch. Toxikol. 26, 203-209.

Boyd, T. C., and Roy, A. L. 1929. The excretion of antimony in the urine. Indian J. Med. Res. 17, 94-108.

Bradbury, M. W. 1997. Transport of iron in the blood-brain-cerebrospinal fluid system. J. Neurochem. 69, 443-454.

Bridges, J. W., Davies, D. S., and Williams, R. T. 1967. Fate of ethyltin and diethyltin derivatives in the rat. Biochem. J. 105, 1261-1267.

Brüggemann, J., Barth, K., and Niesar, K.-H. 1964. Experimental studies on the content of triphenylacetate residues in turnip leaves, ensilage of turnip leaves, and in excrements of animals fed with these products. Zentralbl. Veterinarmed. A. 11, 4-19.

Burgess, J. 1992. Kinetic aspects of chemical speciation. Analyst. 117, 605-611.

Byrne, R. H., Kump, L. R., and Cantrell, K. J. 1988. The influence of temperature and pH on trace metal speciation in seawater. Mar. Chem. 25, 163-181. 
Campbell, P. G. C. 1995. Interactions between trace metals and aquatic organisms: A critique of the free-ion activity model. In Metal Speciation and Bioavailability in Aquatic Systems (A. Tessier and D. R. Turner, eds.), pp. 45-102. John Wiley \& Sons Ltd, New York.

Cancalon, P. 1982. Degeneration and regeneration of olfactory cells induced by $\mathrm{ZnSO}_{4}$ and other chemicals. Tissue Cell. 14, 717-733.

Caruso, J., Wuilloud, R. G., Wuilloud, J. C. A., and Harris, W. R. 2005. Modeling and separation-detection methods to evaluate the speciation of metals for toxicity assessment. J. Toxicol. Environ. Health. this volume.

Carvalho, S. M., and Ziemer, P. L. 1982. Distribution and clearance of ${ }^{63} \mathrm{Ni}$ administered as ${ }^{63} \mathrm{NiCl}_{2}$ in the rat: intratracheal study. Arch. Environ. Contam. Toxicol. 11, 245248.

Cary, E. E., Allaway, W. H., and Miller, M. 1973. Utilization of different forms of dietary selenium. J. Anim. Sci. 36, 285-292.

Chai, Z. F., Zhang, Z. Y., Feng, W. Y., Chen, C. Y., Xu, D. D., and Hou, X. L. 2004. Study of chemical speciation of trace elements by molecular activation analysis and other nuclear techniques. J. Anal. At. Spectrom. 19, 26-33.

Charbonneau, S. M., Tam, G. K. H., Bryce, F., and Collins, B. 1978. Pharmacokinetics and metabolism of inorganic arsenic in the dog. In Proceedings of University of Missouri's 12th Annual Conference of Trace Substances in Environmental Health, (D. D. Hemphill, ed.), pp. 276-283, Columbia, Missouri.

Charleston, J. S., Body, R. L., Bolender, R. P., Mottet, N. K., Vahter, M. E., and Burbacher, T. M. 1996. Changes in the number of astrocytes and microglia in the 
thalamus of the monkey Macaca fascicularis following long-term subclinical methylmercury exposure. NeuroToxicology. 17, 127-138.

Chen, J. Y., Tsao, G. C., Zhao, Q., and Zheng, W. 2001. Differential cytotoxicity of $\mathrm{Mn}(\mathrm{II})$ and $\mathrm{Mn}(\mathrm{III})$ : special reference to mitochondrial [Fe-S] containing enzymes. Toxicol. Appl. Pharmacol. 175, 160-168.

Chen, N. S., Tsai, A., and Dyer, I. A. 1973. Effect of chelating agents on chromium absorption in rats. J. Nutr. 103, 1182-1186.

Cherian, M. G., and Shaikh, Z. A. 1975. Metabolism of intravenously injected cadmiumbinding protein. Biochem. Biophys. Res. Commun. 65, 863-869.

Cikrt, M., and Bencko, V. 1974. Fate of arsenic after parenteral administration to rats, with particular reference to excretion via bile. J. Hyg. Epidemiol. Microbiol. Immunol. $18,113-120$.

Clarkson, T. W. 1979. Effects - General principles underlying the toxic action of metals. In Handbook on the Toxicology of Metals (L. Friberg, G. F. Nordberg and V. Vouk, eds.), Vol. 1, pp. 99-117. Elsevier/North-Holland Biomedical Press, Amsterdam.

Clarkson, T. W. 1993. Molecular and ionic mimicry of toxic metals. Annu. Rev. Pharmacol. 33, 545-571.

Cohen, S. M., Arnold, L. L., Uzvolgyi, E., Cano, M., St John, M., Yamamoto, S., Lu, X., and Le, X. C. 2002. Possible role of dimethylarsinous acid in dimethylarsinic acidinduced urothelial toxicity and regeneration in the rat. Chem. Res. Toxicol. 15, 11501157. 
Coulson, E. J., Remington, R. E., Lynch, K. M. 1935. Metabolism in the rat of the naturally occurring arsenic of shrimp as compared with arsenic trioxide J. Nutr. 10, 255-270.

Crecelius, E. A. 1977. Changes in the chemical speciation of arsenic following ingestion by man. Environ. Health Perspect. 19, 147-150.

Cremer, J. E. 1965. Toxicology and biochemistry of alkyl lead compounds. Occup. Health Rev. 17, 14-19.

Crossgrove, J. S., Allen, D. D., Bukaveckas, B. L., Rhineheimer, S. S., and Yokel, R. A. 2003. Manganese distribution across the blood-brain barrier. I. Evidence for carriermediated influx of managanese citrate as well as manganese and manganese transferrin. NeuroToxicology. 24, 3-13.

Crossgrove, J. S., and Yokel, R. A. 2005. Manganese distribution across the bloodbrain barrier. IV. Evidence for brain influx through store-operated calcium channels. NeuroToxicology, in press.

Cuddihy, R. G., Hale, R. P., and Griffith, W. C. 1974. Inhalation exposures to barium aerosols. Physical, chemical and mathematical analysis. Health Phys. 26, 405-416. Culver, B., Strong, P., and Murray, J. 2001. Boron. In Patty's Toxicology (E. Bingham, B. Cohrssen and C. H. Powell, eds.), Vol. 3, pp. 519-582. John Wlley \& Sons, Inc., New York.

Cummins, L. M., and Kimura, E. T. 1971. Safety evaluation of selenium sulfide antidandruff shampoos. Toxicol. Appl. Pharmacol. 20, 89-96.

Dagle, G. E., Cannon, W. C., Stevens, D. L., and McShane, J. F. 1983. Comparative disposition of inhaled ${ }^{238} \mathrm{Pu}$ and ${ }^{239} \mathrm{Pu}$ nitrates in beagles. Health Phys. 44, 275-277. 
Danielsson, B., Hassoun, E., and Dencker, L. 1982. Embryotoxicity of chromium: distribution in pregnant mice and effects on embryonic cells in vitro. Arch. Toxicol. $51,233-245$.

Danscher, G. 1981. Light and electron microscopic localization of silver in biological tissue. Histochemistry. 71, 177-186.

Darrie, G. 2001. The importance of chromium in occupational health. In Trace Element Speciation for Environment, Food and Health (L. Ebdon, L. Pitts, R. Cornelis, H. Crews, O. F. X. Donard and P. Quevauviller, eds.), pp. 315-330. Royal Society of Chemistry, Thomas Graham House, Science Park, Milton Road, Cambridge.

De Flora, S., Badolati, G. S., Serra, D., Picciotto, A., Magnolia, M. R., and Savarino, V. 1987. Circadian reduction of chromium in the gastric environment. Mutat. Res. 192, 169-174.

De Flora, S., Bagnasco, M., Serra, D., and Zanacchi, P. 1990. Genotoxicity of chromium compounds. A review. Mutat. Res. 238, 99-172.

De Flora, S., Serra, D., Camoirano, A., and Zanacchi, P. 1989. Metabolic reduction of chromium, as related to its carcinogenic properties. Biol. Trace Elem. Res. 21, 179187.

Dean, P. B., Niemi, P., Kivisaari, L., and Kormano, M. 1988. Comparative pharmacokinetics of gadolinium DTPA and gadolinium chloride. Invest. Radiol. 23 Suppl 1, S258-260.

Deane, R., and Bradbury, M. W. 1990. Transport of lead-203 at the blood-brain barrier during short cerebrovascular perfusion with saline in the rat. J. Neurochem. 54, 905914. 
Donard, O. F. X. 2001. Metal speciation for improved environmental management. In Trace Element Speciation for Environment, Food and Health (L. Ebdon, L. Pitts, R. Cornelis, H. Crews, O. F. X. Donard and P. Quevauviller, eds.), pp. 115-126. Royal Society of Chemistry, Thomas Graham House, Science Park, Milton Road, Cambridge.

Dorian, C., Gattone, V. H., and Klaasen, C. D. 1992. Renal cadmium deposition and injury as a result of accumulation of cadmium-metallothionein (CdMT) by the proximal convoluted tubules--A light microscopic autoradiography study with ${ }^{109}$ CdMT. Toxicol. Appl. Pharmacol. 114, 173-181.

Dorman, D. C., Struve, M. F., James, R. A., Marshall, M. W., Parkinson, C. U., and Wong, B. A. 2001. Influence of particle solubility on the delivery of inhaled manganese to the rat brain: manganese sulfate and manganese tetroxide pharmacokinetics following repeated (14-day) exposure. Toxicol. Appl. Pharmacol. $170,79-87$.

Dudley, R. E., Gammal, L. M., and Klaassen, C. D. 1985. Cadmium-induced hepatic and renal injury in chronically exposed rats: likely role of hepatic cadmiummetallothionein in nephrotoxicity. Toxicol. Appl. Pharmacol. 77, 414-426.

Duffus, J. H. 2001. Risk assessment and trace element speciation. In Trace Element Speciation for Environment, Food and Health (L. Ebdon, L. Pitts, R. Cornelis, H. Crews, O. F. X. Donard and P. Quevauviller, eds.), pp. 354-372. Royal Society of Chemistry, Thomas Graham House, Science Park, Milton Road, Cambridge. Ebdon, L., Pitts, L. H., Cornelis, R., Crews, H., Donard, O. F. X., and Quevauviller, P., eds. 2001. Trace Element Speciation for Environment, Food and Health. Royal 
Society of Chemistry, Thomas Graham House, Science Park, Milton Road, Cambridge.

Edel, J., Marafante, E., Sabbioni, E., and Manzo, L. 1983. Metabolic behavior of inorganic forms of antimony in the rat. In 4th International Conference on Heavy Metals in the Environment, Vol. 1, pp. 574-577. CEP Consultants, Ltd., Edinburgh, Heidelberg.

Edel, J., and Sabbioni, E. 1988. Retention of intractracheally instilled and ingested tetrabvalent and pentavalent vanadium in the rat. J. Trace Elem. Electrolytes Health Dis. 2, 23-30.

Eidson, A. F. 1994. The effect of solubility on inhaled uranium compound clearance: a review. Health Phys. 67, 1-14.

Einbrodt, H. J., Wobker, F., and Klippel, H. G. 1972. Experimental studies on the accumulation and distribution of barium sulphate in the rat following inhalation. Int. Arch. Arbeitsmedizin. 30, 237-244.

English, J. C., Parker, R. D., Sharma, R. P., and Oberg, S. G. 1981. Toxicokinetics of nickel in rats after intratracheal administration of a soluble and insoluble form. Am. Ind. Hyg. Assoc. J. 42, 486-492.

Erikson, K. M., Suber, R. L., and Aschner, M. 2002. Glutamate/aspartate transporter (GLAST), taurine transporter and metallothionein mRNA levels are differentially altered in astrocytes exposed to manganese chloride, manganese phosphate or manganese sulfate. NeuroToxicology. 23, 281-288.

Evans, E. 2003. New concepts in speciation analysis. Anal. Bioanal. Chem. 376, 311312. 
Evans, R. W., and Holbrook, J. J. 1975. Differences in the protein fluorecence of the two iron(III)-binding sites of ovotransferrin. Biochem. J. 145, 201-207.

Ezra, F. S., Lucas, D. S., and Russell, A. F. 1984. ${ }^{31}$ P-NMR and ESR studies of the oxidation states of manganese in Staphylococcus aureus. Biochim. Biophys. Acta. 803, 90-94.

Feron, V. J., Arts, J. H., Kuper, C. F., Slootweg, P. J., and Woutersen, R. A. 2001. Health risks associated with inhaled nasal toxicants. Crit. Rev. Toxicol. 31, 313-347.

Finley, B. L., Kerger, B. D., Katona, M. W., Gargas, M. L., Corbett, G. C., and Paustenbach, D. J. 1997. Human ingestion of chromium (VI) in drinking water: pharmacokinetics following repeated exposure. Toxicol. Appl. Pharmacol. 142, 151159.

Foulkes, E. 2001. Mercury. In Patty's Toxicology (E. Bingham, B. Cohrssen and C. Powell, eds.), Vol. 2, pp. 327-352. John Wiley and Sons, Inc., New York.

Foulkes, E. C. 1978. Renal tubular transport of cadmium-metallothionein. Toxicol. Appl. Pharmacol. 45, 505-512.

Friberg, L., Nordberg, G. F., and Vouk, V. B., eds. 1986. Handbook on the Toxicology of Metals. Elsevier, Amsterdam.

Friberg, L., Nordberg, G. F., and Vouk, V. B., eds. 1979. Handbook on the Toxicology of Metals. Elsevier/North-Holland Biomedical Press, Amsterdam.

Gaggelli, E., Berti, F., D'Amelio, N., Gaggelli, N., Valensin, G., Bovalini, L., Paffetti, A., and Trabalzini, L. 2002. Metabolic pathways of carcinogenic chromium. Environ. Health. Perspect. 110 Suppl 5, 733-738. 
Gauthier, E., Fortier, I., Courchesne, F., Pepin, P., Mortimer, J., and Gauvreau, D. 2000. Aluminum forms in drinking water and risk of Alzheimer's disease. Environ. Res. 84, 234-246.

Gellhorn, A., Tupikova, N. A., and Van Dyke, H. B. 1946. The tissue-distribution and excretion of four organic antimonials after single or repeated administration to normal hamsters. J. Pharmacol. Exp. Ther. 87, 169-180.

Gibbons, R. A., Dixon, S. N., Hallis, K., Russell, A. M., Sansom, B. F., and Symonds, H. W. 1976. Manganese metabolism in cows and goats. Biochim. Biophys. Acta. 444, $1-10$.

Goldhaber, S. B. 2003. Trace element risk assessment: essentiality vs. toxicity. Regul. Toxicol. Pharmacol. 38, 232-242.

Goodwin, L. G., and Page, J. E. 1943. A study of the excretion of organic antimony using a polarographic procedure. Biochem. J. 37, 198-209.

Gordon, T., and Fine, J. M. 1993. Metal fume fever. Occup. Med. 8, 504-517.

Goyer, R. A., and Clarkson, T. W. 2001. Toxic effects of metals. In Casarett and Doull's Toxicology - The Basic Science of Poisons (C. D. Klaassen, ed.), pp. 811-867. McGraw-Hill, New York.

Guffanti, A. A., Wei, Y., Rood, S. V., and Krulwich, T. A. 2002. An antiport mechanism for a member of the cation diffusion facilitator family: divalent cations efflux in exchange for $\mathrm{K}^{+}$and $\mathrm{H}^{+}$. Mol. Microbiol. 45, 145-153.

Gunaratnam, M., and Grant, M. H. 2001. The role of glutathione reductase in the cytotoxicity of chromium (VI) in isolated rat hepatocytes. Chem. Biol. Interact. 134, 191-202. 
Gunshin, H., Allerson, C. R., Polycarpou-Schwarz, M., Rofts, A., Rogers, J. T., Kishi, F., Hentze, M. W., Rouault, T. A., Andrews, N. C., and Hediger, M. A. 2001. Irondependent regulation of the divalent metal ion transporter. FEBS Lett. 509, 309-316.

Gunshin, H., Mackenzie, B., Berger, U. V., Gunshin, Y., Romero, M. F., Boron, W. F., Nussberger, S., Gollan, J. L., and Hediger, M. A. 1997. Cloning and characterization of a mammalian proton-coupled metal-ion transporter. Nature. $388,482-488$.

Haase, H., and Beyersmann, D. 2002. Intracellular zinc distribution and transport in C6 rat glioma cells. Biochem. Biophys. Res. Commun. 296, 923-928.

Hamel, F., and Duckworth, W. 1995. The realtionship between insulin and vanadium metabolism in insulin target tissues. Mol. Cell. Biochem. 153, 95-102.

Hancock, R. D., and Martell, A. E. 1996. Hard and soft acid-base behavior in aqueous solution. J. Chem. Educ. 73, 654-661.

Harris, W. R., Friedman, S. B., and Silberman, D. 1984. Behavior of vanadate and vanadyl ion in canine blood. J. Inorg. Biochem. 20, 157-69.

Heath, D. F. 1963. Some problems in the determination of residues in plants and mammals. In Radiation and radioisotopes applied to insects of agricultural importance. Proceedings of the Symposium on the Use and Application of Radioisotopes and Radiation in the Control of Plant and Animal Insect Pests., pp. 185-193. International Atomic Energy Agency, Vienna.

Hentze, M. W., Muckenthaler, M. U., and Andrews, N. C. 2004. Balancing acts: molecular control of mammalian iron metabolism. Cell. 117, 285-297.

Hiles, R. A. 1974. Absorption, distribution and excretion of inorganic tin in rats. Toxicol. Appl. Pharmacol. 27, 366-379. 
Hirano, S., Shimada, T., Osugi, J., Kodama, N., and Suzuki, K. T. 1994. Pulmonary clearance and inflammatory potency of intratracheally instilled or acutely inhaled nickel sulfate in rats. Arch. Toxicol. 68, 548-554.

Hogan, R. B., and Eagle, H. 1944. The pharmacologic basis for the widely varying toxicity of arsenicals. J. Pharmacol. Exp. Ther. 80, 93-113.

Hollins, J. G., and McCullough, R. S. 1971. Radiation dosimetry of internal contamination by inorganic compounds of cobalt: an analysis of cobalt metabolism in rats. Health Phys. 21, 233-246.

Hsieh, H. S., and Ganther, H. E. 1975. Acid-volatile selenium formation catalyzed by glutathione reductase. Biochemistry. 14, 1632-1636.

Hughes, M. 2002. Arsenic toxicity and potential mechanisms of action. Toxicol. Lett. 133, 1-16.

Ishimatsu, S., Kawamoto, T., Matsuno, K., and Kodama, Y. 1995. Distribution of various nickel compounds in rat organs after oral administration. Biol. Trace Elem. Res. 49, $43-52$.

Jakubowski, M. 2001. Zinc and cadmium. In Patty's Toxicology (E. Bingham, B. Cohrssen and C. Powell, eds.), Vol. 2, pp. 253-325. John Wiley and Sons, Inc., New York.

Johnson, C. H., and VanTassell, V. J. 1991. Acute barium poisoning with respiratory failure and rhabdomyolysis. Ann. Emerg. Med. 20, 1138-1142.

Johnson, P. W., and Lee, D.-Y. 1988. Copper absorption and excretion measured by two methods in rats fed varying concentrations of dietary copper. J. Trace Elem. Exp. Med.. 1, 129-141. 
Joselow, M. M., Louria, D. B., and Browder, A. A. 1972. Mercurialism: environmental and occupational aspects. Ann. Intern. Med. 76, 119-130.

Kafritsa, Y., Fell, J., Long, S., Bynevelt, M., Taylor, W., and Milla, P. 1998. Long-term outcome of brain manganese deposition in patients on home parenteral nutrition. Arch. Dis. Child. 79, 263-265.

Kaplan, J. 2002. Mechanisms of cellular iron acquisition: another iron in the fire. Cell. $111,603-606$.

Kasprzak, K. S. 1991. The role of oxidative damage in metal carcinogenicity. Chem. Res. Toxicol. 4, 604-615.

Kasprzak, K. S., and Sunderman, F. W., Jr. 1969. The metabolism of nickel carbonyl${ }^{14}$ C. Toxicol. Appl. Pharmacol. 15, 295-303.

Katz, S. A. 1991. The analytical biochemistry of chromium. Environ. Health Perspect. $92,13-16$.

Katz, S. A., and Salem, H. 1993. The toxicology of chromium with respect to its chemical speciation: a review. J. Appl. Toxicol. 13, 217-224.

Kerger, B. D., Richter, R. O., Chute, S. M., Dodge, D. G., Overman, S. K., Liang, J., Finley, B. L., and Paustenbach, D. J. 1996. Refined exposure assessment for ingestion of tapwater contaminated with hexavalent chromium: consideration of exogenous and endogenous reducing agents. J. Exp. Anal. Environ. Epidemiol. 6, 163-179.

Kern, M., Wisniewski, M., Cabell, L., and Audesirk, G. 2000. Inorganic lead and calcium interact positively in activation of calmodulin. NeuroToxicology. 21, 353-263. 
Kerper, L. E., and Hinkle, P. M. 1997. Cellular uptake of lead is activated by depletion of intracellular calcium stores. J. Biol. Chem. 272, 8346-8352.

Kirchner, D. B. 2002. The spectrum of allergic disease in the chemical industry. Int. Arch. Occup. Environ. Health. 75 Suppl, S107-112.

Klaassen, C. D. 1974. Biliary excretion of arsenic in rats, rabbits, and dogs. Toxicol. Appl. Pharmacol. 29, 447-457.

Klaassen, C. D. 2001. Heavy metals and heavy-metal antagonists. In The Pharmacological Basis of Therapeutics (J. G. Hardman, Limbird, L.E., and Gilman, A.G., ed., pp. 1851-1875. McGraw-Hill, New York.

Kobla, H. V., and Volpe, S. L. 2000. Chromium, exercise, and body composition. Crit. Rev. Food Sci. Nutr. 40, 291-308.

Kono, Y., Takahashi, M. A., and Asada, K. 1976. Oxidation of manganous pyrophosphate by superoxide radicals and illuminated spinach chloroplasts. Arch. Biochem. Biophys. 174, 454-462.

Kortenkamp, A., Ozolins, Z., Beyersmann, D., and O'Brien, P. 1989. Generation of PM2 DNA breaks in the course of reduction of chromium(VI) by glutathione. Mutat. Res. $216,19-26$

Langård, S. 1982. Absorption, transport, and excretion of chromium in man and animals. In Biological and Environmental Aspects of Chromium (S. Langård, ed.), pp. 169-194. Elsevier/North-Holland Biomedical Press., Amsterdam.

Langård, S., and Norseth, T. 1979. Chromium. In Handbook on the Toxicology of Metals. (L. Friberg, G. F. Nordberg and V. Vouk, eds.), pp. 383-397. Elsevier/NorthHolland Biomedical Press, Amsterdam. 
Larsen, E. K., and Berg, T. 2001. Trace element speciation and international food legislation - A Codex Alimentarius position paper on arsenic as a contaminant. In Trace Element Speciation for Environment, Food and Health (L. Ebdon, L. Pitts, R. Cornelis, H. Crews, O. F. X. Donard and P. Quevauviller, eds.), pp. 251-260. Royal Society of Chemistry, Thomas Graham House, Science Park, Milton Road, Cambridge.

Lee, J., Peña, M. M. O., Nose, Y., and Thiele, D. J. 2002. Biomedical characteristics of the human copper transporter Ctr1. J. Biol. Chem. 277, 4380-4387.

Lindgren, A., Vahter, M., and Dencker, L. 1982. Autoradiographic studies on the distribution of arsenic in mice and hamsters administered ${ }^{74} \mathrm{As}$-arsenite or -arsenate. Acta Pharmacol. Toxicol. (Copenhagen). 51, 253-265.

Long, G. J., Rosen, J. F., and Schanne, F. A. 1994. Lead activation of protein kinase C from rat brain. Determination of free calcium, lead, and zinc by ${ }^{19} \mathrm{~F}$ NMR. J. Biol. Chem. 269, 834-837.

Lopez-Quintela, M. A., Knoche, W., and Veith, J. 1984. Kinetics and thermodynamics of complex formation between aluminium (III) and citric acid in aqueous solution. $\mathrm{J}$. Chem. Soc. Faraday Trans. 80, 2313-2321.

Magos, L., Halbach, S., and Clarkson, T. W. 1978. Role of catalase in the oxidation of mercury vapor. Biochem. Pharmacol. 27, 1373-1377.

Mangels, A. R., Moser-Veillon, P. B., Patterson, K. Y., and Veillon, C. 1990. Selenium utilization during human lactation by use of stable-isotope tracers. Am. J. Clin. Nutr. $52,621-627$. 
Marafante, E., Rade, J., Sabbioni, E., Bertolero, F., and Foa, V. 1981. Intracellular interaction and metabolic fate of arsenite in the rabbit. Clin. Toxicol. 18, 1335-1341.

Marafante, E., Vahter, M., and Dencker, L. 1984. Metabolism of arsenocholine in mice, rats and rabbits. Sci. Total Environ. 34, 223-240.

Markovac, J., and Goldstein, G. W. 1988. Picomolar concentrations of lead stimulate brain protein kinase C. Nature. 334, 71-73.

Mazaev, V. T., Tikhonova, Z. I., and Shlepnina, T. G. 1976. Distribution and elimination of tin taken up into the organism in the form of organo-tin compounds. J. Hyg. Epidemiol. Microbiol. Immunol. 20, 392-395.

McConnell, K. P., and Cho, G. J. 1965. Transmucosal movement of selenium. Am. J. Physiol. 208, 1191-1195.

McConnell, K. P., and Hoffman, J. L. 1972. Methionine-selenomethionine parallels in $E$. coli polypeptide chain initiation and synthesis. Proc. Soc. Exp. Biol. Med. 140, 638641.

McConnell, K. P., and Portman, O. W. 1952. Toxicity of dimethyl selenide in the rat and mouse. Proc. Soc. Exp. Biol. Med. 79, 230-231.

Medinsky, M. A., Benson, J. M., and Hobbs, C. H. 1987. Lung clearance and disposition of ${ }^{63} \mathrm{Ni}$ in $\mathrm{F} 344 / \mathrm{N}$ rats after intratracheal instillation of nickel sulfate solutions. Environ. Res. 43, 168-178.

Medinsky, M. A., Cuddihy, R. G., Griffith, W. C., and McClellan, R. O. 1981a. A simulation model describing the metabolism of inhaled and ingested selenium compounds. Toxicol. Appl. Pharmacol. 59, 54-63. 
Medinsky, M. A., Cuddihy, R. G., and McClellan, R. O. 1981b. Systemic absorption of selenious acid and elemental selenium aerosols in rats. J. Toxicol. Environ. Health. 8, 917-928.

Mertz, W. 1969. Chromium occurrence and function in biological systems. Physiol. Rev. 49, 163-239.

Mertz, W. 1995. Risk assessment of essential trace elements: new approaches to setting recommended dietary allowances and safety limits. Nutr. Rev. 53, 179-185.

Miettinen, J. K. 1973. Absorption and elimination of dietary mercury $\left(\mathrm{Hg}^{2+}\right)$ and methylmercury in man. In Mercury, Mercurials and Mercaptans (M. W. Miller and T. W. Clarkson, eds.), pp. 233-243. Charles C. Thomas, Springfield.

Mills, K. C., and Curry, S. C. 1994. Acute iron poisoning. Emerg. Med. Clin. North Am. $12,397-413$.

Moesgaard, S., and Morrill, R. 2001. The need for speciation to realize the potential of selenium in disease prevention. In Trace Element Speciation for Environment, Food and Health (L. Ebdon, L. Pitts, R. Cornelis, H. Crews, O. F. X. Donard and P. Quevauviller, eds.), pp. 261-284. Royal Society of Chemistry, Thomas Graham House, Science Park, Milton Road, Cambridge.

Moore, W., Jr., Malanchuk, M., Crocker, W., Hysell, D., Cohen, A., and Stara, J. F. 1975. Whole body retention in rats of different ${ }^{191} \mathrm{Pt}$ compounds following inhalation exposure. Environ. Health. Perspect. 12, 35-39.

Morel, F. M. M. 1983. Complexaton: Trace Metals and Microorganisms. Principles of Aquatic Chemistry. 301 pages, Wiley-Interscience, New York. 
Morgareidge, K. 1963. Inorganic vs Organic As Metabolism. Food and Drug Research Labs, Inc., Maspeth, NY.

Morin, M., Nenot, J. C., and Lafuma, J. 1972. Metabolic and therapeutic study following administration to rats of ${ }^{238} \mathrm{Pu}$ nitrate - A comparison with ${ }^{239} \mathrm{Pu}$. Health Phys. 23, 475-480.

Mroz, M., Balkissoon, R., and Newman, L. 2001. Beryllium. In Patty's Toxicology (E. Bingham, B. Cohrssen and C. Powell, eds.), Vol. 2, pp. 177-220. John Wiley and Sons, Inc., New York.

Munro, I. C. 1976. Naturally occurring toxicants in foods and their significance. Clin. Toxicol. 9, 647-663.

Nieboer, E., Fletcher, G. G., and Thomassen, Y. 1999. Relevance of reactivity determinants to exposure assessment and biological monitoring of the elements. $J$. Environ. Monit. 1, 1-14.

Nieboer, E., and Richardson, D. H. S. 1980. The replacement of the nondescript term heavy metals by a biologically and chemically significant classification of metal ions. Environ. Pollut. Ser. B. 1, 3-26.

Niyogi, S., and Wood, C. 2003. Effects of chronic waterborne and dietary metal exposures on gill metal-binding: Implications for the biotic ligand model. Human Ecol. Risk Assess. 9, 813-846.

Nordberg, G., and Skerfving, S. 1972. Metabolism. In Mercury in the Environment. An Epidemiological and Toxicological Appraisal (L. Friberg and J. Vostal, eds.), pp. 2991. CRC Press, Cleveland, $\mathrm{OH}$. 
Nordberg, M., Duffas, J., and Templeton, D. 2004. Glossary of terms used in toxicokinetics (IUPAC recommendations 2003). Pure Appl. Chem. 76, 1033-1082.

Norseth, T., Alexander, J., Aaseth, J., and Langård, S. 1982. Biliary excretion of chromium in the rat: a role of glutathione. Acta Pharmacol. Toxicol. (Copenhagen). $51,450-455$.

Oberdörster, G., Ferin, J., and Lehnert, B. E. 1994. Correlation between particle size, in vivo particle persistence, and lung injury. Environ. Health Perspect. 102 Suppl 5, 173-179.

O'Brien, T. J., Ceryak, S., and Patierno, S. R. 2003. Complexities of chromium carcinogenesis: role of cellular response, repair and recovery mechanisms. Mutat. Res. 533, 3-36.

O'Flaherty, E. J. 1996. A physiologically based model of chromium kinetics in the rat. Toxico.l Appl. Pharmacol. 138, 54-64.

Olin, S. S. 1998. Between a rock and a hard place: methods for setting dietary allowances and exposure limits for essential minerals. J. Nutr. 128, 364S-367S.

Otto, G. F., and Maren, T. H. 1950. Studies of chemotherapy of filariasis. Part V. Studies on the pharmacology of arsenamide and related arsenicals. Am. J. Hyg. 51, 353-395.

Overby, L., and Frost, D. 1962. Nonavailability to the rat of the arsenic in tissues of swine fed arsanilic acid. Toxicol. Appl. Pharmacol. 4, 38-43.

Paquin, P. R., Gorsuch, J. W., Apte, S., Batley, G. E., Bowles, K. C., Campbell, P. G., Delos, C. G., Di Toro, D. M., Dwyer, R. L., Galvez, F., Gensemer, R. W., Goss, G. G., Hostrand, C., Janssen, C. R., McGeer, J. C., Naddy, R. B., Playle, R. C., 
Santore, R. C., Schneider, U., Stubblefield, W. A., Wood, C. M., and Wu, K. B. 2002. The biotic ligand model: a historical overview. Comp. Biochem. Physiol. C Toxicol. Pharmacol. 133, 3-35.

Parent, L., Twiss, M. R., and Campbell, P. G. C. 1996. Influences of natural dissolved organic matter on the interaction of aluminum with the microalga chlorella: A test of the free-ion model of trace metal toxicity. Environ. Sci. Technol. 30, 1713-1720.

Park, J. B., Bair, W., and Busch, R. 1972. Progress in beagle dog studies with transuranium elements at Batelle-Northwest. Health Phys. 22, 803-810.

Paustenbach, D. J., Finley, B. L., Mowat, F. S., and Kerger, B. D. 2003. Human health risk and exposure assessment of chromium (VI) in tap water. J. Toxicol. Environ. Health A. 66, 1295-1339.

Petrilli, F. L., Rossi, G. A., Camoirano, A., Romano, M., Serra, D., Bennicelli, C., De Flora, A., and De Flora, S. 1986. Metabolic reduction of chromium by alveolar macrophages and its relationship to cigarette smoke. J. Clin. Invest. 77, 1917-1924.

Philpott, C. C. 2002. Molecular aspects of iron absorption: Insights into the role of HFE in hemochromatosis. Hepatology. 35, 993-1001.

Picard, V., Govoni, G., Jabado, N., and Gros, P. 2000. Nramp 2 (DCT1/DMT1) expressed at the plasma membrane transports iron and other divalent cations into a calcein-accessible cytoplasmic pool. J. Biol. Chem. 275, 35738-35745.

Plankey, B. J., and Patterson, H. H. 1987. Kinetics of aluminum-fulvic acid complexation in acidic waters. Environ. Sci. Technol. 21, 595-601.

POISINDEX® System. L. L. Toll and K. M. Hurlbut, eds,. MICROMEDEX, Greenwood Village, Colorado. 
Pomroy, C., Charbonneau, S. M., McCullough, R. S., and Tam, G. K. 1980. Human retention studies with ${ }^{74}$ As. Toxicol. Appl. Pharmacol. 53, 550-556.

Pott, E., Henry, P., Ammerman, C., Merritt, A., Madison, J., and Miles, R. 1994. Relative bioavailability of copper in a copper-lysine complex for chicks and lambs. Anim. Feed Sci. Technol. 45, 193-201.

Proctor, D. M., Otani, J. M., Finley, B. L., Paustenbach, D. J., Bland, J. A., Speizer, N., and Sargent, E. V. 2002. Is hexavalent chromium carcinogenic via ingestion? A weight-of-evidence review. J. Toxicol. Environ. Health A. 65, 701-746.

Rahola, T., Hattula, T., Korolainen, A., and Miettinen, J. K. 1973. Elimination of free and protein-bound ionic mercury $\left({ }^{203} \mathrm{Hg}^{2+}\right)$ in man. Ann. Clin. Res. 5, 214-219.

Reaney, S. H., Kwik-Uribe, C. L., and Smith, D. R. 2002. Manganese oxidation state and its implications for toxicity. Chem. Res. Toxicol. 15, 1119-1126.

Reiber, S., Kukull, W., and Standish-Lee, P. 1995. Drinking water aluminum and bioavailability. J. Am. Water Works Assoc. 87, 86-100.

Rhoads, K., and Sanders, C. L. 1985. Lung clearance, translocation, and acute toxicity of arsenic, beryllium, cadmium, cobalt, lead, selenium, vanadium, and ytterbium oxides following deposition in rat lung. Environ. Res. 36, 359-378.

Roskams, A. J., and Connor, J. R. 1990. Aluminum access to the brain: a role for transferrin and its receptor. Proc. Natl. Acad. Sci. U. S. A. 87, 9024-9027.

Rowbotham, A. L., Levy, L. S., and Shuker, L. K. 2000. Chromium in the environment: an evaluation of exposure of the UK general population and possible adverse health effects. J. Toxicol. Environ. Health B Crit. Rev. 3, 145-178. 
Rusch, G. M., O'Grodnick, J. S., and Rinehart, W. E. 1986. Acute inhalation study in the rat of comparative uptake, distribution and excretion for different cadmium containing materials. Am. Ind. Hyg. Assoc. J. 47, 754-763.

Rydzynski, K. 2001. Vanadium, niobium, and tantalum. In Patty's toxicology (E.

Bingham, B. Cohrssen and C. H. Powell, eds.), Vol. 3, pp. 1-74. John Wlley \& Sons, Inc., New York.

Schkroeder, H. A., Balassa, J. J., and Tipton, I. H. 1963. Abnormal trace metals in man: titanium. J. Chronic Dis. 16, 55-69.

Schlesinger, R. B. (1995). Deposition and clearance of inhaled particles. In Concepts of Inhalation Technology (R. O. McClelland and R. F. Henderson, eds.), pp. 191-224. Taylor and Francis, Washington, D.C.

Sekaly, A. L. R., Mandal, R., Hassan, N. M., Murimboh, J., Chakrabarti, C. L., Back, M. H., Grégoire, D. C., and Schroeder, W. H. 1999. Effect of metal/fulvic acid mole ratios on the binding of $\mathrm{Ni}(\mathrm{II}), \mathrm{Pn}(\mathrm{II}), \mathrm{Cu}(\mathrm{II}), \mathrm{Cd}(\mathrm{II})$, and $\mathrm{Al}(\mathrm{III})$ by two wellcharacterized fulvic acids in aqueous model solutions. Anal. Chim. Acta. 402, 211221.

Shao, Z., and Suszkiw, J. B. 1991. $\mathrm{Ca}^{2+}$-surrogate action of $\mathrm{Pb}^{2+}$ on acetylcholine release from rat brain synaptosomes. J. Neurochem. $56,568-574$.

Simons, T. J. 1986. The role of anion transport in the passive movement of lead across the human red cell membrane. J. Physiol. (Lond). 378, 287-312.

Sin, Y. M., Lim, Y. F., and Wong, M. K. 1983. Uptake and distribution of mercury in mice from ingesting soluble and insoluble mercury compounds. Bull. Environ. Contam. Toxicol. 31, 605-612. 
Sin, Y. M., Teh, W. F., Wong, M. K., and Reddy, P. K. 1990. Effect of mercury on glutathione and thyroid hormones. Bull. Environ. Contam. Toxicol. 44, 616-622.

Singh, J., Carlisle, D. L., Pritchard, D. E., and Patierno, S. R. 1998. Chromium-induced genotoxicity and apoptosis: relationship to chromium carcinogenesis (review). Oncol. Rep. 5, 1307-1318.

Smith, I., and Carson, B. 1977. Silver. National Institute of Environmental Health Sciences, Research Triangle Park, NC.

Smith, R. P. 1992. A Primer of Environmental Toxicology. Lea and Fibiger, Philadelphia.

Sollman, T., and Schreiber, N. E. 1936. Chemical studies of acute poisoning from mercury bichloride. Arch. Intern. Med. 57, 46-62.

Squibb, K. S., and Fowler, B. A. 1984. Intracellular metabolism and effects of circulating cadmium-metallothionein in the kidney. Environ. Health Perspect. 54, 31-35.

Squibb, K. S., Pritchard, J. B., and Fowler, B. A. 1984. Cadmium-metallothionein nephropathy: relationships between ultrastructural/biochemical alterations and intracellular cadmium binding. J. Pharmacol. Exp. Ther. 229, 311-321.

Sternberg, J., and Imbach, A. 1967. Metabolic studies with seleniated compounds. II. Turnover studies with $\mathrm{Se}^{75}$-methionine in rats. Int. J. Appl. Radiat. Isotopes. 18, 557568.

Stokinger, H. E. 1981. The metals. In Patty's Industrial Hygiene and Toxicology (G. D. Clayton and F. E. Clayton, eds.), Vol. 2A Toxicology, pp. 1493-2060. John Wiley \& Sons, New York.

Stoner, H. B., Barnes, J. M., and Duff, J. I. 1955. Studies on the toxicity of alkyl tin compounds. Br. J. Pharmacol. 10, 16-25. 
Sunderman, F. W., Jr. 2001. Nasal toxicity, carcinogenicity, and olfactory uptake of metals. Ann. Clin. Lab. Sci. 31, 3-24.

Sunderman, F. W., Jr., and Selin, C. E. 1968. The metabolism of nickel-63 carbonyl. Toxicol. Appl. Pharmacol. 12, 207-218.

Suszkiw, J., Toth, G., Murawsky, M., and Cooper, G. P. 1984. Effects of $\mathrm{Pb}^{2+}$ and $\mathrm{Cd}^{2+}$ on acetylcholine release and $\mathrm{Ca}^{2+}$ movements in synaptosomes and subcellular fractions from rat brain and Torpedo electric organ. Brain Res. 323, 31-46.

Suzuki, S., Itoh, M., and Ohmichi, M. 1998. Selective uptake of selenite by red blood cells. Analyst. 123, 63-67.

Suzuki, T. 1969. Neurological symptoms from concentration of mercury in the brain. In Chemical Fallout (M. W. Miller and G. G. Berg, eds.), pp. 245-257. Charles C. Thomas, Springfield.

Swensson, A. 1952. Investigations on the toxicity of some organic mercury compounds which are used as seed disinfectants. Acta Med. Scand. 143, 365-383.

Swietlik, R. 1998. Meaning of the term "speciation" in environmental chemistry. Wiadomosci Chemiczne. 52, 587-595.

Takagi, Y., Okada, A., Sando, K., Wasa, M., Yoshida, H., and Hirabuki, N. 2002. Evaluation of indexes of in vivo manganese status and the optimal intravenous dose for adult patients undergoing home parenteral nutrition. Am. J. Clin. Nutr. 75, 112118.

Tallkvist, J., Bowlus, C. L., and Lönnerdal, B. 2000. Functional and molecular responses of human intestinal Caco-2 cells to iron treatment. Am. J. Clin. Nutr. 72, 770-775. 
Tam, G. K., Charbonneau, S. M., Bryce, F., and Sandi, E. 1982. Excretion of a single oral dose of fish arsenic in man. Bull. Environ. Contam. Toxicol. 28, 669-673.

Taylor, A. 1996. Biochemistry of tellurium. Biol. Trace Elem. Res. 55, 231-239.

Taylor, D. M. 1962. The absorption of cobalt from the gastrointestinal tract of the rat. Phys. Med. Biol. 6, 445-451.

Teaf, C. M., Tuovila, B. J., Zillioux, E. J., Shipp, A., Lawrence, G., and van Landingham, C. 2004. Nickel carcinogenicity in relation to the health risks from residual oil fly ash. Human Ecol. Risk Assess. 10, 665-682.

Templeton, D. M. 1999. Biomedical aspects of trace element speciation. Fresenius J. Anal. Chem. 363, 505-511.

Templeton, D. M., Ariese, F., Cornelis, R., Danielsson, L. G., Muntau, H., Van Leeuwen, H. P., and Lobinski, R. 2000. Guidelines for terms related to chemical speciation and fractionation of elements. Definitions, structural aspects, and methodological approaches. Pure Appl. Chem. 72, 1453-1470.

Thomson, C. D., Stewart, R. D., and Robinson, M. F. 1975. Metabolic studies in rats of $\left[{ }^{75}\right.$ Se]selenomethionine and of ${ }^{75}-$ Se incorporated in vivo into rabbit kidney. Br. J. Nutr. 33, 45-54.

Uthus, E. O., and Seaborn, C. D. 1996. Deliberations and evaluations of the approaches, endpoints and paradigms for dietary recommendations of the other trace elements. J. Nutr. 126, 2452S-2459S.

Vahter, M., Akesson, A., Lind, B., Bjors, U., Schutz, A., and Berglund, M. 2000. Longitudinal study of methylmercury and inorganic mercury in blood and urine of 
pregnant and lactating women, as well as in umbilical cord blood. Environ. Res. 84, 186-194.

Vahter, M., and Marafante, E. 1983. Intracellular interaction and metabolic fate of arsenite and arsenate in mice and rabbits. Chem. Biol. Interact. 47, 29-44.

Vahter, M., and Norin, H. 1980. Metabolism of ${ }^{74}$ As-labeled trivalent and pentavalent inorganic arsenic in mice. Environ. Res. 21, 446-457.

Van Landeghem, G. F., De Broe, M. E., and D'Haese, P. C. 1998. Al and Si: Their speciation, distribution, and toxicity. Clin. Biochem. 31, 385-397.

Verity, M. A. 1995. Nervous system. In Metal Toxicity (R. Goyer, C. D. Klaassen, D. Curtis and M. R. Waalkes, eds.), pp. 199-235. Academic Press, San Diego.

Vitarella, D., Wong, B. A., Moss, O. R., and Dorman, D. C. 2000. Pharmacokinetics of inhaled manganese phosphate in male Sprague-Dawley rats following subacute (14day) exposure. Toxicol. Appl. Pharmacol. 163, 279-285.

Wapnir, R. A., and Stiel, L. 1986. Zinc intestinal absorption in rats: specificity of amino acids as ligands. J. Nutr. 116, 2171-2179.

WHO (World Health Organization). 1973. Trace Elements in Human Nutrition: Manganese. Report of a WHO Expert Committee. Technical Report Service, 532, WHO, Geneva, Switzerland. p. 34-36.

WHO (World Health Organization). 1990. Methylmercury. Environmental Health Criteria, 144 pages, Geneva.

WHO (World Health Organization). 1991. Inorganic Mercury. Environmental Health Criteria, 118 pages, Geneva. 
WHO (World Health Organization), in collaboration with the Food and Agriculture Organization of the United Nations and the International Atomic Energy Agency. 1996. Trace Elements in Human Nutrition and Health. World Health Organization, Geneva.

Wiegand, H. J., Ottenwalder, H., and Bolt, H. M. 1985. Fast uptake kinetics in vitro of ${ }^{51} \mathrm{Cr}(\mathrm{VI})$ by red blood cells of man and rat. Arch. Toxicol. 57, 31-34.

Wilhelm, M., Jäger, D. E., and Ohnesorge, F. K. 1990. Aluminium toxicokinetics. Pharmacol. Toxicol. 66, 4-9.

Williams, P. R., and Paustenbach, D. J. 2002. Risk characterization: principles and practice. J. Toxicol. Environ. Health B Crit. Rev. 5, 337-406.

Windisch, W. 2002. Interaction of chemical species with biological regulation of the metabolism of essential trace elements. Anal. Bioanal. Chem. 372, 421-425.

Winship, K. A. 1988. Toxicity of tin and its compounds. Adverse Drug React. Acute Poisoning Rev. 7, 19-38.

Yeoh, T. S., Lee, A. S., and Lee, H. S. 1986. Absorption of mercuric sulphide following oral administration in mice. Toxicology. 41, 107-111.

Yokel, R. A. 2001. Aluminum toxicokinetics at the blood-brain barrier. In Aluminium and Alzheimer's Disease (C. Exley, ed.), pp. 233-260. Elsevier, New York.

Yokel, R. A., Crossgrove, J. S., and Bukaveckas, B. L. 2003. Manganese distribution across the blood-brain barrier II. Manganese efflux from the brain does not appear to be carrier mediated. NeuroToxicology. 24, 15-22.

Yuann, J. M., Liu, K. J., Hamilton, J. W., and Wetterhahn, K. E. 1999. In vivo effects of ascorbate and glutathione on the uptake of chromium, formation of chromium(V), 
chromium-DNA binding and 8-hydroxy-2'-deoxyguanosine in liver and kidney of Osteogenic Disorder Shionogi rats following treatment with chromium(VI). Carcinogenesis. 20, 1267-1275.

Zhong, W., Zhang, Q., Yan, Y., Yue, S., Zhang, B., and Tang, W. 1997. Reaction of a platinum(IV) complex with native Cd, Zn-metallothionein in vitro. J. Inorg. Biochem. $66,179-185$.

Zhou, B., and Gitschier, J. 1997. hCTR1: a human gene for copper uptake identified by complementation in yeast. Proc. Natl. Acad. Sci. U S A. 94, 7481-7486. 


\section{Figure 1. An example page from the toxicokinetics database.}

\section{Distribution - Mercury $(\mathrm{Hg})$}

- $\quad \mathrm{Hg}(0)$ vapor dissolves in the metallic atomic form in plasma and rapidly diffuses into erythrocytes. Oxidation in erythrocytes and tissues to $\mathrm{Hg}(\mathrm{II})$ occurs within minutes. $\mathrm{Hg}(\mathrm{II})$ is not able to penetrate these barriers $\mathrm{WHO}$. 1991). Enough $\mathrm{Hg}(0)$ persists long enough in plasma to reach the blood-brain barrier and enter the brain.

- $\mathrm{Hg}(0)$ vapor rapidly diffuses across alveolar membranes because this monatomic gas is lipophilic (Clarkson, 1979).

- After acute $\mathrm{Hg}(0)$ vapor exposure about $1 \%$ of the absorbed dose is deposited in the mouse, rat, rabbit and primate brain, $\sim 10$-fold more $\mathrm{Hg}$ than after an intravenous injection of the same dose of $\mathrm{Hg}(\mathrm{II})$ (Berlin and Johansson, 1964; Berlin et al.. 1969).

- Lipophilic mercurials rapidly cross the erythrocyte membrane, bind to internal ligands, and primarily affect internal systems. lonic $\mathrm{Hg}$ species primarily bind to surface ligands and affect membrane functions. They penetrate to the cell interior slowly (Rothstein. 1973). Rat erythrocyte uptake of methyl $\mathrm{Hg}$ was 10 -times that of phenyl $\mathrm{Hg}$ and 100 -times that of $\mathrm{Hg}(\mathrm{II})$ (Ulfvarson. 1962). Methyl $\mathrm{Hg}$ may be transported across the erythrocyte membrane as a complex with glutathione (Jocelyn, 1972). A significant percentage of the organic mercurial body burden, e.g., following phenyl $\mathrm{Hg}$ acetate exposure, was found in the erythrocytes of rats, rabbits, and dogs (Swensson et al.. 1959; Klaassen. 2001).

- $\quad \mathrm{Hg}(\mathrm{II})$ exists in blood plasma as diffusible and non-diffusible species. More than $99 \%$ of $\mathrm{Hg}(\mathrm{II})$ is bound to plasma albumin and globulins (Berlin and Gibson, 1963; Jakubowski et al., 1970). These non-diffusible forms are unable to enter the brain (Clarkson, 1979). The remaining $<1 \%$ is ultrafilterable and probably $\mathrm{Hg}(\mathrm{II})$ complexes with sulfhydryl compounds of low molecular weight. $\mathrm{Hg}(0)$ and methyl $\mathrm{Hg}$ distribute to all organs more efficiently than inorganic $\mathrm{Hg}(\mathrm{II})$.

- Placental transfer, and resultant fetal effects, is $\mathrm{Hg}$ chemical species dependent. Organic mercurials such as methyl $\mathrm{Hg}$ are quite lipophilic. Organic mercurials, $\mathrm{Hg}(0)$ and $\mathrm{Hg}$ vapor can rapidly cross the placental barrier. $\mathrm{Hg}(\mathrm{II})$ does not and concentrates in the placenta (Miller et al.. 1988). Concentrations are generally higher in umbilical cord blood than maternal blood (WHO. 1991). The fetal $\mathrm{Hg}$ concentration is higher after organic $\mathrm{Hg}$ than $\mathrm{Hg}(\mathrm{II})$ exposure and 4-40-fold higher after $\mathrm{Hg}(0)$ than after $\mathrm{Hg}(\mathrm{II})$ exposure. $\mathrm{Hg}$ (II) crosses the placenta after reduction to $\mathrm{Hg}(0)$ in tissues (Clarkson et al.. 1972; WHO. 1991; Horvat. 2001).

- The ratio of $\mathrm{Hg}$ in the brain compared to plasma was $\sim 2$ to 3 for alkyl mercurials versus $\sim 1$ for inorganic phenylmercurials $(T a k e d a$ et af., 1968). Organic mercurials and $\mathrm{Hg}(0)$ can cross the blood-brain barrier to reach higher brain concentrations than $\mathrm{Hg}(\mathrm{II})$. $\mathrm{The}$ rate constants of brain $\mathrm{Hg}$ uptake after an intraperitoneal injection of methyl $\mathrm{Hg}$ chloride and $\mathrm{Hg}(\mathrm{II})$ chloride were 4.8 and $0.6 \times 10^{-3} \mathrm{~h}^{-1}$, respectively (Aihara and Sharma, 1986). However, computed transfer constants for penetration of methyl $\mathrm{Hg}$ and $\mathrm{Hg}(\mathrm{II})$ into brain were $2.1 \times 10^{-3}$ and $1.9 \times 10^{-3} \mathrm{ml}$ blood per gram tissue per hour, respectively. The authors suggested $\mathrm{Hg}(\mathrm{II})$ might cross the blood-brain barrier by simple diffusion of a low molecular weight complex (Farris et al.. 1993).

- In addition to diffusion, methyl $\mathrm{Hg}$ is transported by the large neutral amino acid carrier to the brain as a complex with thiol-containing cysteine which mimics methionine (Aschner and Clarkson, 1988; Kerper et al., 1992). It may be transported by the same carrier to other tissues as the same complex or as a glutathione complex (Clarkson, 1994) or by the $y$-glutamyl transpeptidase pathway (Meister and Anderson. 1983). Phenyl $\mathrm{Hg}$ less effectively penetrates brain and placental barriers than methyl $\mathrm{Hg}$. Dimethyl $\mathrm{Hg}$ does not cross the blood-brain barrier until converted to methyl $\mathrm{Hg}$. Following equivalent doses in mice or rats, more $\mathrm{Hg}$ is found in blood and less in brain with ethyl $\mathrm{Hg}$ than with methyl $\mathrm{Hg}$ (Magos, 2001).

- Organic $\mathrm{Hg}$ shows greater accumulation in the brain whereas inorganic $\mathrm{Hg}$ is mainly retained in the kidneys (Berlin and Ulberq. $1963 \mathrm{a}$ b. 무 Suzuki, 1969; Clarkson, 1972; Friberg and Vostal, 1972; Berlin et al., 1973; Plotrowski and Inskip, 1981).

- There was more accumulation of an $\mathrm{N}$-butylmercury in blood than muscle than ethyl mercury compounds (Takeda et al. 1968). Over time, more $\mathrm{Hg}$ accumulates in the lysosomal/peroxosomal fraction after a single dose of $\mathrm{HgCl}_{2}$ than after methyl $\mathrm{Hg}(\mathrm{Norseth}$. 1969).

- There is greater retention of $\mathrm{Hg}$ in animals following $\mathrm{Hg}$ chloride exposure than the much less water soluble $\mathrm{Hg}$ sulfide (Foulkes, 2001).

Link to Distribution Periodic Table

Link to Database Index

Comments to Robert Yokel, Ph.D. Last Modified: 
Figure 2. Pathways involved in $\mathrm{Cr}$ metabolism in erythrocytes (bottom) and formation of DNA lesions by $\mathrm{Cr}(\mathrm{VI})$ (top). $\mathrm{Cr}(\mathrm{III})$ is poorly absorbed by cells while $\mathrm{Cr}(\mathrm{VI})$ is brought into the cell via sulfate anion channels. Once in the cell $\mathrm{Cr}(\mathrm{VI})$ is reduced to $\mathrm{Cr}(\mathrm{III})-$ a mutagenic form of $\mathrm{Cr}$ (adapted from O'Brien et al., 2003).

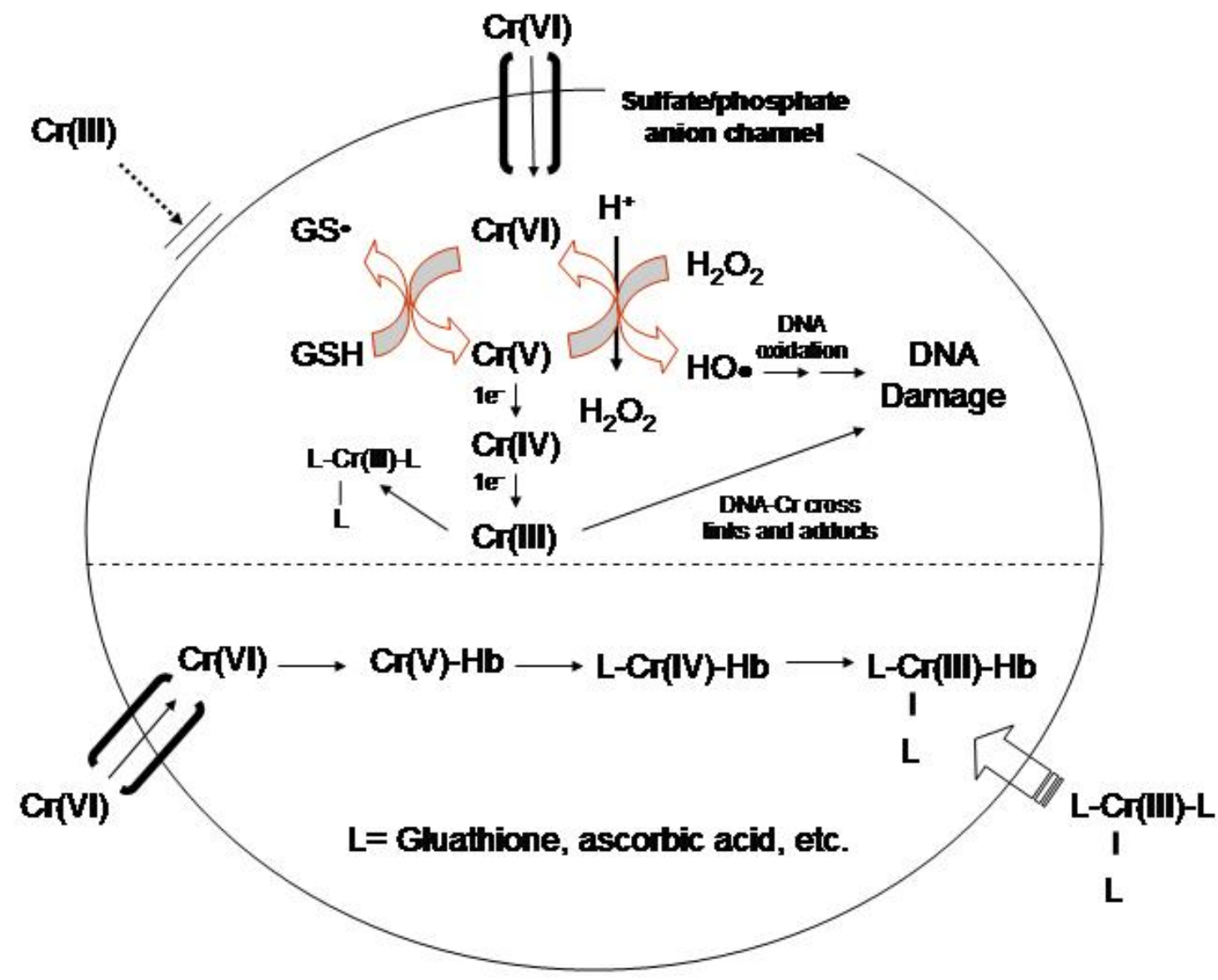


Figure 3. Relationship between ionic and covalent indices for the metal and metalloid ions. The covalent index has been divided into three classifications, Class A (oxygen seeking; bottom), intermediate (center) and Class B (sulfur and nitrogen seeking; top). From (Nieboer et al., 1999). Reproduced with permission.

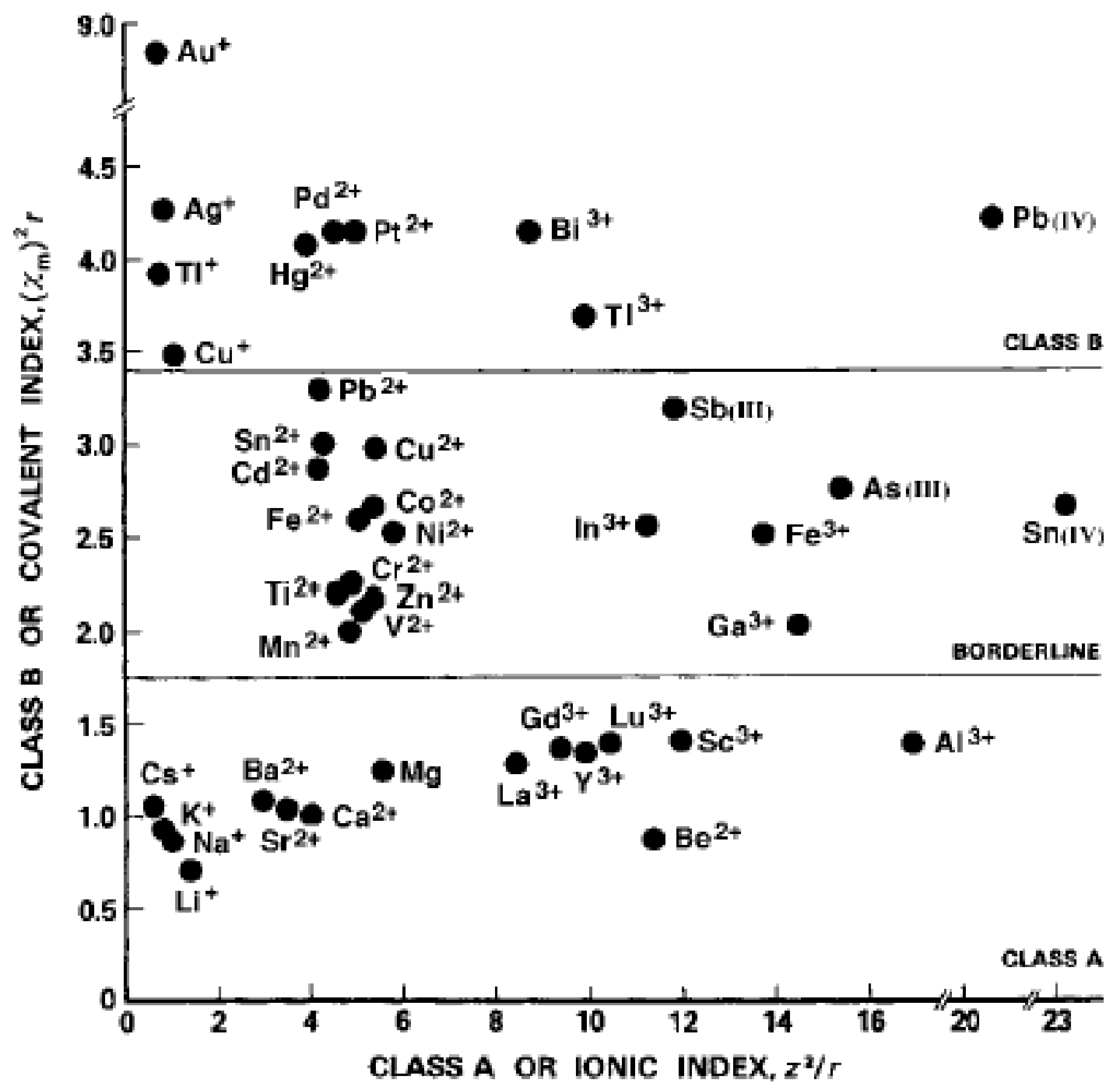


Table 1. Examples of the influence of valence on the clearance of metals.

\begin{tabular}{|c|c|c|c|}
\hline \multicolumn{2}{|c|}{$\begin{array}{c}\text { Metal in valence state in left column cleared } \\
\text { more rapidly than in valence state in next } \\
\text { column }\end{array}$} & \multirow{2}{*}{$\begin{array}{l}\text { Cleared } \\
\text { From lung }\end{array}$} & \multirow{2}{*}{$\begin{array}{c}\text { Reference } \\
\text { (Edel and } \\
\text { Sabbioni, 1988) }\end{array}$} \\
\hline $\mathrm{V}(\mathrm{V})$ & $\mathrm{V}(\mathrm{IV})$ & & \\
\hline vanadyl sulfate V(IV) & $\begin{array}{c}\text { sodium orthovanadate } \\
\mathrm{V}(\mathrm{V})\end{array}$ & $\begin{array}{l}\text { From } \\
\text { tissues }\end{array}$ & $\begin{array}{c}\text { (Hamel and } \\
\text { Duckworth, 1995) }\end{array}$ \\
\hline $\mathrm{Cr}(\mathrm{IV})$ & $\mathrm{Cr}(\mathrm{III})$ & Into bile & $\begin{array}{c}\text { (Norseth et al., } \\
\text { 1982) }\end{array}$ \\
\hline $\mathrm{Cr}(\mathrm{III})$ & $\mathrm{Cr}(\mathrm{IV})$ & $\begin{array}{c}\text { From } \\
\text { mammal, } \\
\text { due to } \\
\text { less cell } \\
\text { entry of } \\
\text { Cr(III) }\end{array}$ & \\
\hline $\mathrm{Mn}(\mathrm{II}) \alpha_{2}$-macroglobulin & $\mathrm{Mn}(\mathrm{III})$ transferrin & $\begin{array}{c}\text { From } \\
\text { mammal }\end{array}$ & $\begin{array}{c}\text { (Gibbons et al, } \\
1976)\end{array}$ \\
\hline $\mathrm{As}(\mathrm{V})$ & As(III) & Into urine & $\begin{array}{c}\text { (Hogan and } \\
\text { Eagle, 1944) } \\
\text { (Cikrt and Bencko, } \\
\text { 1974) }\end{array}$ \\
\hline$\left(\mathrm{Na}_{3} \mathrm{AsO}_{3}\right) \mathrm{As}(\mathrm{III})$ & $\left(\mathrm{Na}_{2} \mathrm{HAsO}_{4}\right)(\mathrm{As}(\mathrm{V})$ & Into bile & $\begin{array}{c}\text { (Cikrt and Bencko, } \\
1974)\end{array}$ \\
\hline $\mathrm{As}(\mathrm{V})$ & As(III) & $\begin{array}{l}\text { From } \\
\text { organs }\end{array}$ & \\
\hline $\mathrm{Sb}(\mathrm{V})$ & $\mathrm{Sb}(\mathrm{III})$ & $\begin{array}{c}\text { From } \\
\text { mammals, } \\
\text { including } \\
\text { humans }\end{array}$ & $\begin{array}{c}\text { (Boyd and Roy, } \\
\text { 1929; Goodwin } \\
\text { and Page, 1943; } \\
\text { Abdallah and Saif, } \\
\text { 1962) }\end{array}$ \\
\hline $\mathrm{Sb}(\mathrm{V})$ & $\mathrm{Sb}(\mathrm{III})$ & Into urine & $\begin{array}{c}\text { (Gellhorn et al., } \\
\text { 1946; Edel et al., } \\
\text { 1983) }\end{array}$ \\
\hline $\mathrm{Sb}(\mathrm{III})$ & $\mathrm{Sb}(\mathrm{V})$ & Into feces & $\begin{array}{c}\text { (Otto and Maren, } \\
\text { 1950; Edel et al., } \\
\text { 1983) }\end{array}$ \\
\hline $\mathrm{U}(\mathrm{VI})$ & $\mathrm{U}(\mathrm{IV})$ & Excretion & $\begin{array}{c}\text { (Stokinger, 1981), } \\
\text { p. } 2005\end{array}$ \\
\hline
\end{tabular}


Table 2. Toxicity of multiple valence metals as a function of the valence state.

\begin{tabular}{|c|c|c|c|}
\hline $\begin{array}{l}\text { LESS TOXIC } \\
\text { VALENCE }\end{array}$ & $\begin{array}{l}\text { MORE TOXIC } \\
\text { VALENCE }\end{array}$ & $\begin{array}{l}\text { LESS TOXIC } \\
\text { VALENCE }\end{array}$ & REFERENCES \\
\hline & As(III) & $\mathrm{As}(\mathrm{V})$ & $\begin{array}{l}\text { (Hughes, 2002; } \\
\text { Aposhian et al., 2003) }\end{array}$ \\
\hline $\mathrm{Cr}(\mathrm{III})<\mathrm{Cr}(\mathrm{VI})$ & $\begin{array}{c}\mathrm{Cr}(\mathrm{IV}), \mathrm{Cr}(\mathrm{V}) \\
\text { intermediates }\end{array}$ & $\mathrm{Cr}(\mathrm{III})<\mathrm{Cr}(\mathrm{VI})$ & $\begin{array}{l}\text { (Kasprzak, 1991; } \\
\text { Templeton et al., 2000) }\end{array}$ \\
\hline $\mathrm{Hg}(\mathrm{I})$ & $\mathrm{Hg}(\mathrm{II})$ & & (Klaassen, 2001) \\
\hline $\mathrm{Mn}(\mathrm{II})$ & $\mathrm{Mn}(\mathrm{III})$ & $\mathrm{Mn}(\mathrm{IV})$ & $\begin{array}{l}\text { (Chen et al., 2001; } \\
\text { Reaney et al., 2002) }\end{array}$ \\
\hline $\mathrm{Te}(\mathrm{II})$ & $\mathrm{Te}(\mathrm{IV})$ & $\mathrm{Te}(\mathrm{VI})$ & $\begin{array}{l}\text { (Goyer and Clarkson, } \\
\text { 2001) }\end{array}$ \\
\hline $\mathrm{U}(\mathrm{IV})$ & $\mathrm{U}(\mathrm{VI})$ & & $\begin{array}{l}\text { ATSDR Toxicological } \\
\text { Profile for Uranium }\end{array}$ \\
\hline
\end{tabular}

